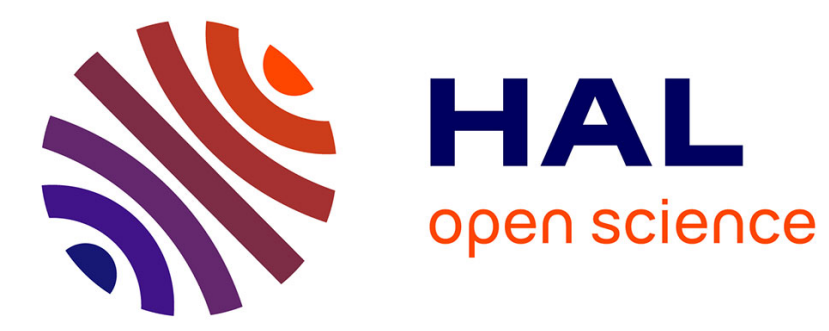

\title{
The Effect of Non-Work Related Health Events on Career Outcomes: An Evaluation in the French Labor Market
}

Emmanuel Duguet, Christine Le Clainche

\section{To cite this version:}

Emmanuel Duguet, Christine Le Clainche. The Effect of Non-Work Related Health Events on Career Outcomes: An Evaluation in the French Labor Market. 2014. hal-01292099

\author{
HAL Id: hal-01292099 \\ https://hal.science/hal-01292099 \\ Preprint submitted on 22 Mar 2016
}

HAL is a multi-disciplinary open access archive for the deposit and dissemination of scientific research documents, whether they are published or not. The documents may come from teaching and research institutions in France or abroad, or from public or private research centers.
L'archive ouverte pluridisciplinaire HAL, est destinée au dépôt et à la diffusion de documents scientifiques de niveau recherche, publiés ou non, émanant des établissements d'enseignement et de recherche français ou étrangers, des laboratoires publics ou privés. 
The Effect of Non-Work Related Health Events on Career Outcomes:

An Evaluation in the French Labor Market

EMMANuEl DugueT AND CHRISTINE LE ClAinCHE 
ISSN 2110-5472 


\title{
The Effect of Non-Work Related Health Events on Career Outcomes: An Evaluation in the French Labor Market ${ }^{1}$
}

\author{
Emmanuel Duguet \\ Université Paris Est, ERUDITE, UPEC, UPEMLV, TEPP (FR CNRS 3435) \\ and Centre d'Etudes de l'Emploi \\ and \\ Christine le Clainche \\ Centre d'Etudes de l'Emploi and LAMETA (UMR CNRS 5474)
}

Revised, April 2014

\begin{abstract}
This paper investigates whether chronic illnesses and injuries have a significant impact on individual performance in the labor market. We use the "Santé et Itinéraires Professionnels" (SIP, "Health and Labor Market Histories") survey, conducted in France in the period 2006-2007. We evaluate the impact of chronic illnesses and accidents using propensity score matching. We find that chronic illness and injuries have negative effects on career outcomes and that women are more likely to claim minimum assistance revenue when such events occur. Moreover, while the initial health shock generally has long-lasting effects, it differs across genders and according to the nature of the health event: the results for men reveal a prevalence of short-run effects following accidents and a prevalence of long-run effects following chronic illnesses. We do not observe similar results for women: both chronic illnesses and accidents have long-run effects.
\end{abstract}

JEL Classification: I10, J20, J31.

Keywords: accident, chronic illness, labor, revenue.

\footnotetext{
${ }^{1}$ This research received financial support from Drees and Dares (Research Department of the French Ministry of Labour and Social Affairs). We thank the following individuals for their comments on earlier versions of this paper: Chantal Cases, Thierry Debrand, Eric Delattre, François Gardes, Claude Mathieu, Véronique Simonnet, Nicolas Sirven, Christophe Starzec and Jérôme Wittwer. We also thank the participants in the following seminars and conferences: Health and Safety at Work Conference (Universita Cattolica Milano, July 2010); Journée de Microéconomie Appliquée (University of Angers, June 2010; University of Brest 2012), Journée des Economistes de la Santé Français (University of Lyon, December 2010), Journées d'Etudes sur l'Hétérogénéité des Comportements Individuels (ANR-06-Blan-0140, University of Paris I, April 2011) and the Journée Santé-Travail, (Chaire Santé, Risque Assurance, University of Paris-Dauphine, September 2011).
} 


\title{
L'effet des événements de santé non reliés au travail sur les carrières professionnelles : une évaluation sur le marché du travail français
}

\begin{abstract}
Résumé
Cet article analyse l'effet d'une maladie chronique et des accidents sur les performances sur le marché du travail. Nous utilisons l'enquête «Santé Intinéraires professionnels (SIP) réalisée en 2006-2007. Nous évaluons l'impact des maladies chroniques et des accidents en utilisant la méthode du score de propension et trouvons que ces événements de santé affectent négativement la carrière professionnelle, les femmes se trouvant plus souvent bénéficiaires du RMI. Par ailleurs, si le premier choc de santé a des effets de long terme en général, il est différencié par genre et par la nature du choc de santé : les effets pour les hommes montrent une domination des effets de court terme s'agissant des accidents tandis qu'à long terme ce sont les effets des maladies chroniques qui dominent. Nous ne trouvons pas de résultats similaires pour les femmes, les accidents ayant aussi des effets de long terme.
\end{abstract}

Mots clés: accidents, maladies chroniques, marché du travail, revenus.

Classement JEL : I10, J20, J31. 


\section{Introduction}

How do health shocks impact activity and income over the life cycle? The main effect operates by depreciating health capital that in turn depreciates human capital. Therefore, isolated health events can influence a worker's entire career path. If we consider individuals at the beginning of their careers, health shocks may reduce both their ability to train and their productivity at a given level of training. If we consider individuals in the middle of their careers, a health shock may force them into lower quality jobs and reduce their earnings. In this paper, we estimate the impact of the health events that occurred throughout individual careers on end-of-period performance variables. We consider two types of health events: accidents and chronic diseases. We examine whether a health shock is able to modify the full career path that follows it. Therefore, we will be able to examine whether health shocks have a long-lasting effect on labor market performance. We consider several types of performance variables. First, we consider labor market participation, as a depreciation of human capital may imply a lower ability to work. Second, we assess the monthly income obtained at the end of the period, which is a summary of career outcomes. We complement this information with data on whether the individual received minimum assistance revenue. Third, we also use a subjective worker satisfaction index concerning the entire career path.

To estimate the influence of health shocks, we cannot simply compare the performance of workers who experienced a health shock with that of other workers for the following reasons. First, the likelihood of experiencing a health shock varies with individual characteristics. Childhood living conditions are known to have a significant impact on the probability of suffering from an accident or a chronic disease, and we should compare individuals who faced similar childhood living conditions. Second, the career consequences of a health shock differ from one individual to another. Workers who completed higher education are more likely to work in an office than workers with a primary education, and office jobs are more compatible with certain diseases than manual labor. For example, a broken leg after a ski accident is not compatible with working in construction or transportation, but it is compatible with office work. Therefore, individuals with different education levels may not have the same career path after the same health shock. More generally, we should control for differences in individual characteristics at labor market entry. These include the education level attained just before entering the labor market and any variables that may influence labor market performance. Several studies using French data show that women and foreign-born workers face hiring discrimination and, occasionally, wage discrimination (Duguet et al., 2012; Meurs and Ponthieux, 2000). Therefore, we included the following three control variables: mother's nationality, father's nationality and whether the worker was born in France (as this confers French citizenship). We will also account for the age of the worker both because the consequences of a health shock depend on it and because older workers may also face discrimination in the labor market (Riach and Rich, 2010). 
The methodology we employ to control for childhood conditions, education capital and discrimination is propensity score matching, introduced by Rosenbaum and Rubin (1983). The goal of this method is to recover the results that we would obtain if health shocks affected workers at random. Rosenbaum and Rubin demonstrate that we need to match workers based on the probability that they will suffer from a health shock. The intuition for this is as follows: if worker A has the same probability of having a health shock as worker B and worker A had a health shock while worker B did not, then it is as if the health shock were distributed between these two workers at random. The probability of facing a health shock is known as the propensity score in the literature, and hence, we match workers based on the propensity score.

Overall, we find that the first health shock has long-lasting effects on workers' career paths. We also find that the magnitude of the effect of the health shock differs across genders and depends on the age at which the worker received this health shock.

The second section of the paper presents the related literature and our contribution. Section 3 presents the data and methodology employed in the estimation. The results are discussed in the fourth section, which is followed by the conclusion.

\section{Related literature}

A number of studies have provided evidence on the impact of health on earnings and employment (see Currie and Madrian (1999) for a survey). The results obtained thus far depend partly on the type of sample used, the health measures considered and the econometric methodology employed. A widespread result is that health capital has a greater effect on the number of hours worked than on wages (Chikiros and Nestel (1981, 1985); Chirikos (1993); Mitchell and Burkhauser (1990). For France, evidence of early retirement and labor market exit has been found (Barnay (2005); Blanchet and Debrand (2007), Debrand and Sirven (2009); Behaghel, Blanchet, Debrand, Roger (2011)). Less attention has been devoted to the effect of health on labor market participation and longterm unemployment from the beginning of the career (Garcia Gomez, 2011). A paper by Tessier and Wolff (2005) on France demonstrates that health affects workforce participation from the beginning of the career. Jusot et al. (2006) underlined that persons whose pathologies are recognized as long-term diseases were more likely to be out of the labor market than those who declared themselves in poor health. However, a recent paper by Haan and Myck (2009) based on German data found a persistent association between poor health and unemployment. Comparable results were obtained by Lindeboom, Llena-Nozal and van der Klauw (2006), who stressed the importance of poor living conditions during early childhood in explaining poor health in adulthood ${ }^{2}$.

\footnotetext{
${ }^{2}$ A growing literature considers the consequences of early childhood conditions on adult health (see, for example, Case, Fertig, Paxson (2005); Wadsworth, Butterworth (2006); Trannoy, Tubeuf, Jusot, Devaux (2010) and Economou, Theodossiou (2011)).
} 
In most studies focusing on the link between health and employment, health capital is proxied by self-reported health measures. While a number of studies emphasize that self-reported health measures are highly correlated with mortality (see, for instance, Idler, Benyamini, 1997) and the consumption of medical care, self-reported measures do not always provide a good summary of the severity of diseases (Lanoë, 2005). Moreover, some studies highlighted the weaknesses of the links between self-reported health measures and labor market variables, particularly with respect to early retirement decisions (Anderson, Burkhauser, 1985; Bazzoli, 1985, Stern, 1989, Bound 1991, Bound et al. 1999). First, there are scale effects, meaning that some individuals have opinions regarding their health that do not conform to their actual health status (Lindeboom, Van Doorslaer, 2004). Second, self-reported measures may not be independent of labor market status (Garcia-Gomez, LopezNicholas, 2006). Third, the measurement error created by the use of proxy variables does not necessarily result from a random process. For instance, there could be a justification bias: the individuals who reduce their working time or exit the labor market are more likely to report poor health, functional limitations or work-related limitations. There are several strategies to surmount these problems such as employing instrumental variables methods where the health measure is instrumented by a series of indicators of functional limitations to obtain a measure of health that is purged of measurement bias (for a recent example, see Zuchelli et al. 2012) ${ }^{3}$.

Measuring accidents is generally simpler, as they are associated with one single event and captured using declarative or administrative data. Few studies have focused on accidents. One such study was conducted by Moller-Dano (2005), who investigated whether road accidents have a causal impact on disposable income, earnings, employment and public transfer income in Denmark, using the propensity score matching method. She found that older injured persons and low-income individuals have significantly lower disposable incomes than comparable non-injured persons. In the short and long term, employment rates were lower for injured men than for non-injured men belonging to the reference group. No effect was found for women. Moreover, reduced earnings were observed for men and for older women. Crichton, Stillman, and Hyslop (2011) conducted a study on this subject in New Zealand. They found a strong negative impact of injuries on employment and earnings. The authors also found that long-lasting injuries had more of an impact on women, older workers and low-income workers ${ }^{4}$.

We employ two health indicators in this study. The first is a dummy variable for the existence of severe chronic diseases recognized by the French health administration (Affections de longue durée, lit. long-term diseases). We construct this indicator to exclude diseases that are explicitly recognized

\footnotetext{
${ }^{3}$ We employ a similar strategy in another work.

${ }^{4}$ Note also that a recent paper by Halla and Zweimuller (2011) uses accidents occurring on the way to and from work to identify the causal effects of health on labor market outcomes.
} 
as professional, and we also remove diseases that we believe, given the epidemiological literature, are potentially dubious regarding the possible interactions with the professional sphere. The second health indicator is a dummy variable for accidents. Relatively fewer studies have focused on accidents. In this paper, we consider three types of accidents: domestic, sport and road accidents. We excluded on-thejob accidents because they imply higher labor market participation before the accident, and this could bias our estimates. ${ }^{5}$ The method we employ is also related to instrumental variables in the following way: we match individuals based on the likelihood that they will suffer from an accident or a disease, and these probabilities depend exclusively on instrumental variables, such as childhood living conditions.

\section{The data}

We use the "Sante et Itinéraires Professionnels" (henceforth, SIP) survey conducted in France in 2006-2007. This survey is retrospective and collects information on individuals' entire professional careers. It is the first survey in France that jointly accounts for health events and the career paths of individuals. The survey addresses several topics: childhood living conditions, occupation (inactive, unemployed or employed), household incomes and health.

In most of our analysis, we use global accident dummies and global chronic disease dummies, which indicate the existence of at least one event during the entire career. However, to refine our results, we also consider the date of the first health event, an accident or a chronic illness. The date of the first health event will only be used when we compare events that occurred early in the career with events that occurred late in the career. The scope of the analysis is restricted to individuals aged between 19 and 55 years. We adopt this restriction because, in France, after reaching 55 years of age, individuals can benefit from legal dispositions to exit the labor market ("pre-retirement"). This program was recently reduced but was still in effect during the period covered by the survey. We also exclude retired workers. Overall, our sample consists of three sub-samples: individuals without accidents or injuries $(\mathrm{N}=4804)$, called the reference sample; individuals with illnesses only $(\mathrm{N}=1105)$; and individuals with injuries only $(\mathrm{N}=970)$. This convention excludes individuals with both accidents and injuries. Using this approach, we will be able to measure the effect of "pure" health shocks.

We wish to estimate the effect of health events on the population at the time of the survey (the end of 2006). To do so, we need to disentangle the effects of the health events from the effects of other explanatory variables. We first present the sample statistics and then the matching methodology.

\footnotetext{
${ }^{5}$ The topic of the relationship between labor market participation and working accidents is beyond the scope of this paper and should be addressed in a specific study including the estimation of a system of Limited Dependent Variables.
} 


\section{Measurement of chronic illnesses and injuries}

\section{Chronic or severe illnesses}

In SIP, the available data available on chronic illnesses are more detailed than the standard selfdeclared measures. To identify chronic diseases, we report on epidemiologists' views of diseases causing limitations (such as the WHO and IDC) and the French administrative classification of longterm diseases ("Affections de Longue Durée" or ALD, lit. Long-Term Diseases). In the SIP survey, the data set is very detailed with respect to the type of disease from which an individual suffers.

In the SIP survey, workers report chronic illnesses, but we restrict their self reports by requiring that they satisfy the definition of long-term diseases provided by the "Sécurite Sociale" (the French Health Care administration), namely, the so-called Affections de longue durée (ALD). Thus, the chronic illnesses that we retained in our study are also recorded as long-term diseases (ALD) in the database. In France, such diseases are eligible for full reimbursement, and hence, the Health Care administration assesses them carefully. We thus obtain an objective health measurement ${ }^{6}$.

We retained the following long-term diseases: cardio-vascular diseases, cancers, incurable deafness, chronic hearing impairment (tinnitus), severe or chronic lung diseases, severe or chronic liver diseases, severe or chronic rheumatism, diabetes, severe or chronic eye disorders (impossible to correct), severe or chronic psychiatric disorders, epilepsy, addictions, HIV or other severe diseases.

\section{Sample definition}

Age: 19 to 55 years old

Excluding retired workers

Excluding work-related health problems

We retain the following chronic diseases:

Cardiovascular diseases (3.7\% of all chronic diseases)

Cancers $(3.2 \%)$

Lung diseases (18.9\%)

Deafness, tinnitus (3.7\%)

Liver disease (1.5\%)

Slipped disc (23.8\%)

Bones and articulation diseases $(9.0 \%)$

Diabetes $(9.8 \%)$

Vision problems that are difficult or impossible to correct (1.5\%)

\footnotetext{
${ }^{6}$ Note that these long-term diseases are very carefully assessed by the doctors who report them to the Health Care Administration (Sécurité Sociale) for their patients. For a disease to be clinically demonstrated, it must be on a list of 30 pathologies (at the time of the survey). Moreover, the Health Care Administration regularly checks the patients in this category. The patients have no way to influence their inclusion in the ALD category.
} 
Severe mental illness $(12.1 \%)$

Epilepsy (1.7\%)

Addiction to alcohol and other products except tobacco (0.6\%)

HIV and other severe diseases (10.6\%)

Table 1: Self-reported health and chronic illness dummy variable

\begin{tabular}{lcccc}
\hline Self-reported Health & $\begin{array}{c}\text { Reference } \\
\text { sample* } \\
\text { (1) }\end{array}$ & $\begin{array}{c}\text { Chronic illness } \\
\text { sample } \\
\text { (2) }\end{array}$ & (2)-(1) & Sifference \\
\hline Very good & $44.7 \%$ & $7.9 \%$ & $-36.8 \%$ & 23.5 \\
Good & $47.8 \%$ & $34.5 \%$ & $-13.2 \%$ & 6.0 \\
Average & $7.2 \%$ & $42.4 \%$ & $+35.1 \%$ & 18.2 \\
Poor & $0.2 \%$ & $12.5 \%$ & $+12.3 \%$ & 11.0 \\
Very poor & $0.1 \%$ & $2.7 \%$ & $+2.6 \%$ & 4.8 \\
\hline * Reference sample: no chronic illness & or accident reported; **: All differences are \\
significant at the 5\% level. & & & &
\end{tabular}

The indicator we employ is a binary variable indicating the presence or absence of such a chronic disease. To assess its quality, we compare it to the self-reported health indicator that is also available in the survey (Table 1). We find that the chronic illness sample has a much lower selfreported health indicator, as good or very good health falls from $92.5 \%$ in the reference sample to $42.4 \%$ in the chronic illness sample. The percentage of poor or very poor health increases from $0.3 \%$ to $15.2 \%$. However, if we compare the self-reported indicator to the types of illness reported by the respondents, there seems to be an excessive number of "average health" observations in the chronic illness sample. This could result from "average" not having the same meaning in the reference sample, where no chronic illness or accident is reported, and the chronic illness sample. This difference provides a motivation to retain the more objective chronic illness dummy variable as our health indicator in this study. Finally, we also remove the professional chronic diseases, as they imply a greater participation in the labor market than the general population before the illness appeared, and this selection could have affected our estimates. 


\section{Accidents}

To take accidents into account, we consider the section of the questionnaire related to accidents, which includes automobile accidents, sport accidents and domestic accidents. We exclude workplace accidents and car accidents occurring during the commute because they involve a greater participation in the labor market than the general population before the accident, and this selection could have affected our estimates.

\section{Descriptive statistics concerning health and injuries}

Table 2 provides the sample statistics for women. We first compare the women in the reference sample with the women in the accident sample (columns (1) and (2), difference (2)-(1)). The women who had an accident are on average older and less educated and had experienced worse childhood living conditions. The labor market performance of the two groups is also different. Women who had an accident work less, have less income, are more often the recipient of minimum assistance revenue and have a lower degree of satisfaction regarding their professional careers.

The chronic illness sample (column (3), difference (3)-(1)) shares similar characteristics with the accident sample. Women with a chronic illness are older and less educated and had experienced worse childhood living conditions. Their labor market performance is also lower than that of the women in the reference sample. They work less, have less income, are more often a recipient of minimum assistance revenue and are less satisfied with their professional careers.

Table 3 provides the same comparison for men. We find similar results for men and women; the only difference is that the magnitude of the disadvantage entailed by health events seems somewhat lower for men than for women.

It is clear the differences in childhood living conditions and education alone could explain the differences in both health status and labor market performance that we observe; hence, an econometric method is needed to disentangle the effect of health from the effects of the other variables.

\section{Methodology}

Our reference group is not a control group, as the sample statistics show, and this is why we cannot rely on the mean performance comparisons in tables 2 and 3 (called "naïve estimators" in the literature). In this paper, we follow the approach developed by Rosenbaum and Rubin (1983, 1985). We wish to measure the effect of poor health (chronic illness or injury) on labor market performance variables. Therefore, we should evaluate the difference between the performance that an individual has 
when in poor health and the performance the same individual would have achieved when in good health. The latter quantity is called the counterfactual. There are many ways to estimate a counterfactual. In this paper, we employ nearest neighbor matching using the propensity score.

Let $\mathrm{y}_{1, \mathrm{i}}$ be the performance of individual $i$ in poor health and $\mathrm{y}_{0, \mathrm{i}}$ that individual's performance in good health. The evaluation problem is a result of our inability to observe both quantities simultaneously. We either observe ${ }^{y_{1, i}}$ when the individual is in poor health or observe $\mathrm{y}_{0, \mathrm{i}}$ when the individual is in good health. The observable data are therefore:

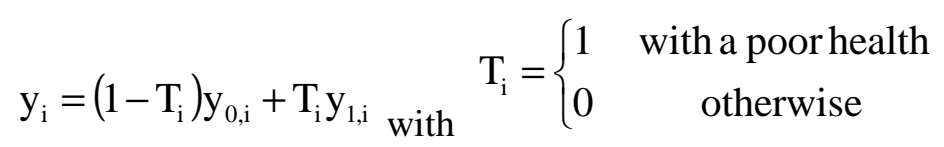

The usual parameter of interest in the literature is the average effect of the treatment on the treated (henceforth, ATT), defined as:

$$
A T T=E\left(y_{1}-y_{0} \mid T=1\right)=E\left(y_{1} \mid T=1\right)-E\left(y_{0} \mid T=1\right)
$$

However the ATT cannot be identified without further assumptions, as $E\left(\mathrm{y}_{0} \mid \mathrm{T}=1\right)$ is not observable. The assumption of random selection is not satisfied in our study because there are several characteristics that may influence both the health status and performance variables (such as childhood living conditions). Conditioning on a vector of covariates X, the ATT becomes:

$$
\operatorname{ATT}(\mathrm{X})=\mathrm{E}\left(\mathrm{y}_{1}-\mathrm{y}_{0} \mid \mathrm{T}=1, \mathrm{X}\right)=\mathrm{E}\left(\mathrm{y}_{1} \mid \mathrm{T}=1, \mathrm{X}\right)-\mathrm{E}\left(\mathrm{y}_{0} \mid \mathrm{T}=1, \mathrm{X}\right)
$$

where $\mathrm{X}$ is a vector of control variables that are not affected by the treatment. In this paper, we match on observables to identity a causal treatment effect on the treated (see, for instance, Deheija and Wahba, 2002). The ATT may be identified by introducing the following Conditional Independence Assumption:

$$
\mathrm{E}\left(\mathrm{y}_{0} \mid \mathrm{T}=1, \mathrm{X}\right)=\mathrm{E}\left(\mathrm{y}_{0} \mid \mathrm{T}=0, \mathrm{X}\right)
$$

This assumption implies that, conditional on $\mathrm{X}$, the expected potential outcome in the case of no treatment is identical for both the treated and the non-treated groups. Thus, the observed outcome for individuals in poor health may be used to measure the potential outcome for individuals in good health conditional on the individual characteristics $\mathrm{X}$.

When the set of observed characteristics is sufficiently large, matching should enable us to consistently estimate the causal effects of poor health on the performance variables. Rosenbaum and 
Rubin (1983) demonstrate that instead of conditioning on a high-dimension X, the covariates can be controlled for by controlling for a real-valued function of $\mathrm{X}, \mathrm{P}(\mathrm{X})$, called the propensity score. It is defined as the probability of receiving the treatment (in our case, poor health). This implies that:

$$
\mathrm{E}\left(\mathrm{Y}_{0} \mid \mathrm{T}=1, \mathrm{P}(\mathrm{X})\right)=\mathrm{E}\left(\mathrm{Y}_{0} \mid \mathrm{T}=0, \mathrm{P}(\mathrm{X})\right)
$$

The intuition for this result is as follows: if two individuals have the same probability of being in poor health, and the first individual is in poor health while the other is not, then the allocation of poor health between these two individuals can be considered random, and we can use the second individual as a counterfactual for the first individual. We follow the initial approach of Rosenbaum and Rubin (1983). The estimation procedure is as follows:

1. We divide the observations in two groups: treated and not treated. The non-treated group is called the reservoir. We estimate the propensity scores using a Probit model, which is presented in the appendix.

2. Sort the treated individuals at random and run a loop over $\mathrm{S}$ different orderings of their data.

3. For each ordering of the data, perform a loop over all individuals in the treated group, with $i=1, \ldots, N_{1}$. Their order is random and specific to each of the $\mathrm{S}$ orderings. Select the $i$-th individual in the treated group, with propensity score $\pi_{1 i}$.

4. Select the individual in the reservoir that has the nearest propensity score (i.e., the probability of being treated) and compute the performance difference between the treated individual and the individual selected from the reservoir.

Formally, let $y_{1 i}$ be the performance of the $i$-th treated individual with propensity score $\pi_{1 i}$ $\left(i=1, \ldots, \mathrm{N}_{1}\right)$. Let $y_{0 j}$ be the performance of the $j$-th reservoir individual with propensity score $\pi_{0 j}\left(j=1, \ldots, \mathrm{N}_{0}^{i}\right)$, where $\mathrm{N}_{0}^{i}$ is the number of individuals remaining in the reservoir at the beginning of the $i$-th step of the loop. Select individual $j^{*}(i)$ from the reservoir, satisfying:

$$
j^{*}(i)=\arg \min _{j}\left|\pi_{1 i}-\pi_{0 j}\right|
$$

and compute the performance difference:

$$
\Delta y_{i}=y_{1, i}-y_{0, j^{*}(i)}
$$

5. Drop individual $j^{*}(i)$ from the reservoir and return to step 3 .

6. Compute the average performance difference for each ordering:

$$
\operatorname{ATT}_{\mathrm{s}}=\frac{1}{\mathrm{~N}_{1}} \sum_{i=1}^{\mathrm{N}_{1}} \Delta y_{i}
$$

7. Once all $\mathrm{S}$ estimations have been made, take the mean performance over the $\mathrm{S}$ orderings: 


$$
\mathrm{ATT}=\frac{1}{\mathrm{~S}} \sum_{\mathrm{S}=1}^{\mathrm{S}} \mathrm{ATT}_{\mathrm{S}}
$$

Notice that the size of the reservoir decreases at each step of the loop because we drop one individual each time; therefore, the size of the reservoir at the beginning of the $i$-th step of the loop equals $\mathrm{N}_{0}^{i}=\mathrm{N}_{0}+1-i$, where $\mathrm{N}_{0}$ is the initial size of the reservoir (i.e., the number of not treated individuals). As our reservoir includes more individuals than the treated group does, we can match all treated individuals, and there is no loss of observations. Therefore, this treatment estimator can be directly compared to the naïve (difference-in-means) estimator.

We performed our estimation procedure on $S=100000$ different orderings of the data to avoid the possibility that our results depend on a specific ordering. The goal of this last statistical treatment is to reduce the variance in the ATT estimator to minimize the probability of obtaining an extreme outcome. As is well known, the mean ATT has a lower variance than the one-sample ATT. This property of the mean explains why we do not need to take $S=N_{1}$ !, which is impossible in practice. We simply need a large number in the following sense. Let $\theta$ be the variance in the one-sample ATT $_{\mathrm{s}}$ estimator, then according to the standard formula:

$$
\mathrm{V}(\mathrm{ATT})=\theta\left(\frac{1}{S}+\rho \times \frac{S-1}{S}\right)
$$

where $\rho>0$ is the correlation coefficient between two one-sample estimators $\mathrm{ATT}_{\mathrm{s}}$. Taking $S=$ 100000 is sufficient to guarantee that $1 / S \simeq 0$ and $(S-1) / S \simeq 1$; hence, we obtain the variance:

$$
\mathrm{V}(\mathrm{ATT}) \simeq \theta \rho<\mathrm{V}\left(\mathrm{ATT}_{\mathrm{s}}\right), \forall \mathrm{s} \text {. }
$$

The value of $\rho$ is inversely related the size of the reservoir because the correlation is created by the observations that are common to several estimators. The smaller the size of the reservoir, the higher the probability that two one-sample estimator $\mathrm{ATT}_{\mathrm{S}}$ have observations in common and, therefore, that they are correlated. In our application, the reservoirs are large, approximately five times the size of the treated sample, and hence, the decline in the variance may be significant; therefore, this is also the case for the probability of obtaining an extreme outcome.

The estimations were performed with SAS-IML.

\section{Results}

All of the regressions are performed separately for men and women, for several reasons. Among these reasons, men and women do not occupy the same types of jobs in the labor market, and they do not have the same probabilities of suffering from certain chronic illnesses, such as the different types of cancer. They are also paid different wages, and the predominant role of women in the education of children may affect their labor market participation relative to men. By separating men from women, we wish to increase the homogeneity of both our health and performance variables. 
We will present the global impact of the health events and two variants. The two variants aim to assess the robustness of our results. The first variant refers to the age at the time the health events occur. The second variant modifies the list of chronic illnesses. Both variants confirm the overall results.

\section{Impact of chronic illness on performance measures}

Table 4 presents the effects of the first health events, which can have long-lasting effects on the end-of-period performance variables, as the third variant shows. Women who had an accident have lower levels of labor market participation and are more likely to belong to the lowest income class. They also more frequently depend on minimum assistance revenue and have a lower degree of satisfaction in their professional careers. Chronic illness has a comparable effect on women's performance in the labor market.

Men who experience a health event also have lower levels of labor market participation and are more likely to belong to the lowest income class, but they are not more frequently recipients of minimum assistance revenue. They also have a lower career satisfaction. The effect of chronic illnesses is similar to the effect of accidents.

Overall, all workers suffer in a similar way from their first health event (accident or chronic illness). However, note that the first accident comes 9 years sooner than the first chronic illness (according to the median times), and hence, the short-term impact of an accident is likely to be stronger than the short-term impact of a chronic illness (table A.1). We only find one significant difference between genders. While the health shocks do not influence men's probability of relying on minimum assistance revenue, it increases this probability for women. This could be related to the fact that women have, on average, less interesting careers than men, and hence, a health shock is more likely to drive them toward the lowest income class than men.

\section{First variant: the age at the time the health events occur}

Controlling for the age at the time the health event occurs allows us to distinguish the impact of shocks that occur early in the professional career from those that occurred recently. However, doing so creates a data constraint: the number of available observations diminishes. To minimize the effect of the reduction in sample size, we decided to retain the median age as the reference point. The median age for the first accident is 24 , while the median age for the first chronic illness is 33 . The distributions of the ages at the first health event are given in Figures 1 and 2. The results are reported in Table 5 for accidents and in Table 6 for chronic illnesses.

For women, early accidents (before 24 years of age) reduce labor market participation and increase the probability of being in the lowest income class (Table 5). For men, we only observe a decline in labor market participation. The late accidents (after 24 years of age) have a somewhat stronger effect. The probability of being in the lowest income class increases to a greater extent, and 
the probability of being in the highest income class decreases. The only significant gender difference is the one we identified previously: women are more likely to rely on minimum assistance revenue than men. This is true irrespective of their age at the time of the first health shock.

The results on women's labor market participation could be explained as follows: an early accident would drive some women out of the labor market, while the late accidents would simply reduce the number of hours worked. These results can be explained by the fact that experienced workers have stronger job protections than young workers and can reduce their hours worked when suffering from a chronic illness (see Duguet and Le Clainche, 2012a, on cancer). We observe similar results for men with a chronic illness.

Figure 1: Age at first health event, women

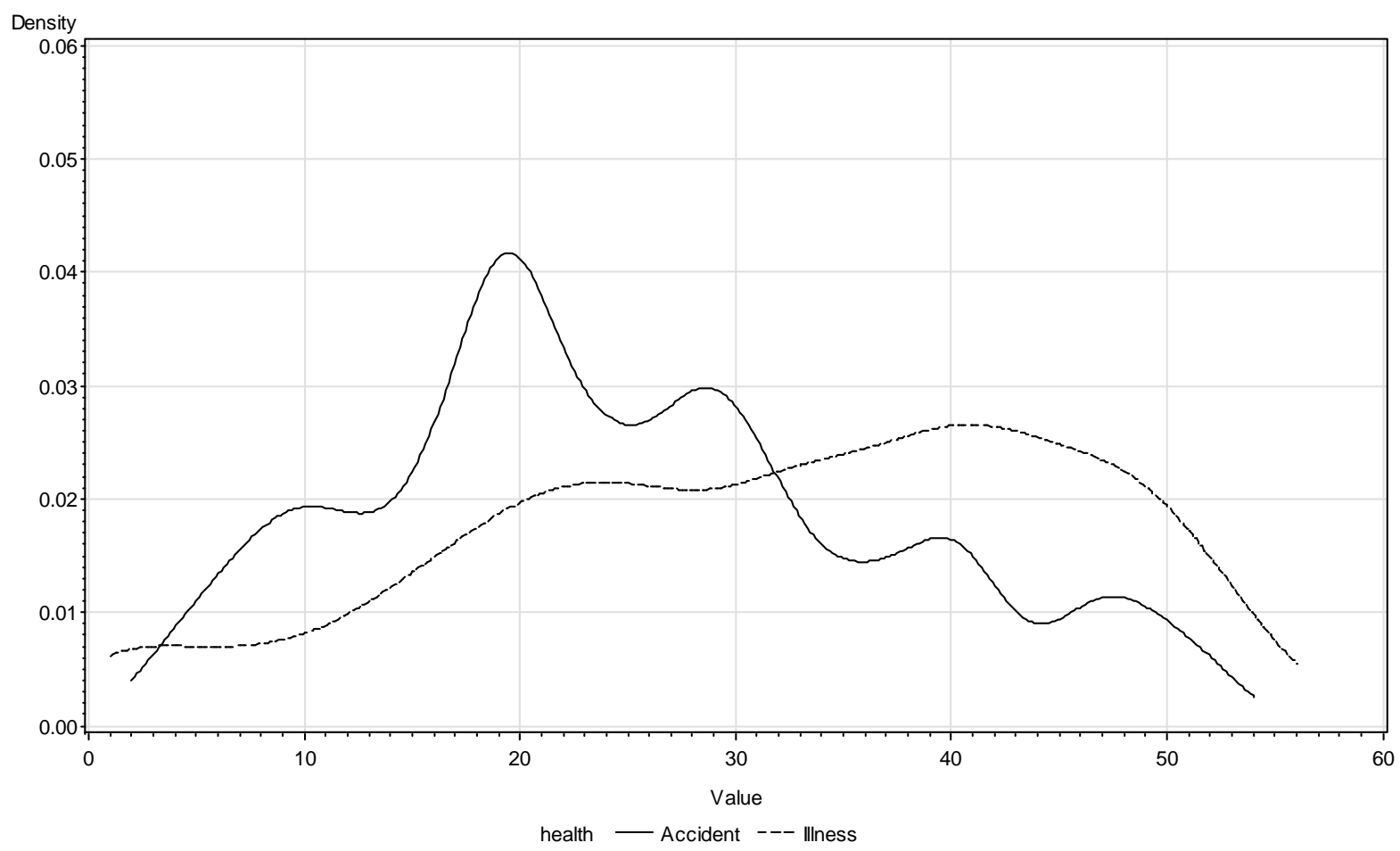




\section{Figure 2: Age at first health event, men}

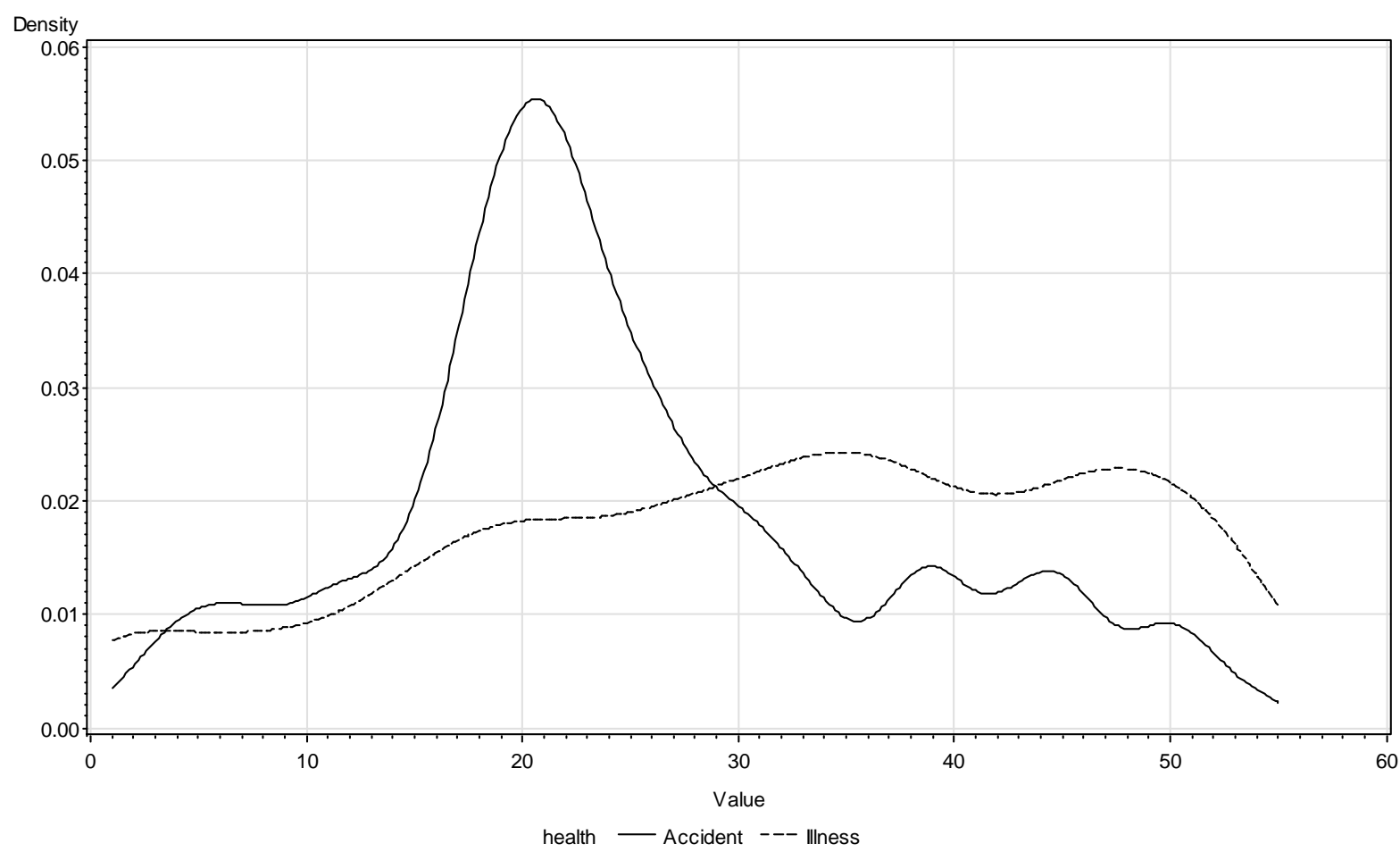

The effects of early and late chronic illnesses are reported in Table 6 and present a similar picture. Early illnesses have a lower impact than late illnesses. The only interesting variant of the global results is found for women. Only late illnesses contribute to increasing women's likelihood of receiving minimum assistance revenue. Therefore, the overall results are robust to the age variant. We note that the effect of chronic illness is compatible with the results obtained by Duguet and Le Clainche (2012a) on cancer. The occurrence of cancer reduced both income and satisfaction at work.

\section{Second variant: the type of chronic illness}

A second robustness check concerns the type of chronic illnesses considered (Table 7). We estimated the following variant: although we have taken care to only consider work-unrelated health events, it is still possible that some of these health events are partly related to working conditions; therefore, we dropped the most probable culprits from the definition of our chronic disease variable. The chronic illnesses that we dropped are the following: deafness, tinnitus, slipped disc, bone diseases and articulation diseases. We find that the remaining chronic illnesses reduce labor market participation and increase the probability of being in the lowest income class. At first glance, the other effects on minimum assistance revenue and career satisfaction seem to vanish. However, the coefficients are similar to those presented in the other tables, meaning that the differences come from the standard errors. As our sample size is substantially reduced by dropping the previous list of 
chronic illnesses from the sample, we cannot exclude the possibility that it is an artifact of the reduced sample size implied by the more restrictive definition of chronic illnesses. ${ }^{7}$

Third variant: Are the effects long lasting? An exploratory analysis

The data allow us, to a certain extent, to evaluate whether the health events' effects are long lasting. The basic notion is to relate the individual contributions to the ATT to the time lag between the health event and the outcome measurement. We proceed by local averaging, which can be interpreted as a non-parametric Nadaraya-Watson estimator. More precisely, the ATT can be written as:

$$
\mathrm{ATT}=\frac{1}{\mathrm{~N}_{1}} \sum_{i=1}^{\mathrm{N}_{1}} \Delta y_{i} \text { with } \Delta y_{i}=\frac{1}{\mathrm{~S}} \sum_{\mathrm{s}=1}^{\mathrm{S}} \Delta y_{i}^{S}
$$

Therefore, $\Delta y_{i}$ is the contribution of the $i$-th individual to the ATT. At this point, we can associate one lag, denoted $d_{i}$, with each value of $\Delta y_{i}$. Now consider two extreme approaches. The first would be to use a scatter plot of $\left(\Delta y_{i}, d_{i}\right)$. Unfortunately, this is not feasible because, with dummy variables, $\Delta y_{i}^{S} \in\{-1,0,1\}$. The use of $S$ different draws slightly modifies that property: $\Delta y_{i} \in$ $[-1,+1]$. This is illustrated in Figure 3. This figure plots the individual ATT contributions against the individual lags. To obtain the ATT, one computes the average of all points in Figure 3.

Figure 3: Individual contributions to ATT against time lags

(labor market participation, women, accident)

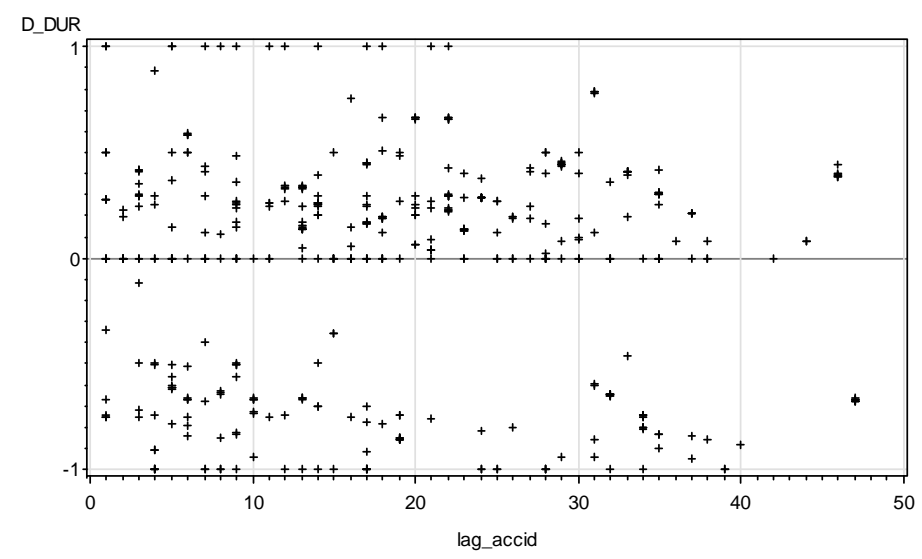

Figure 4: Average with a large window yields the ATT

(labor market participation, women, accident)

\footnotetext{
${ }^{7}$ The general argument is the following: the standard error of an empirical mean $\bar{x}$ computed on sample of size $\mathrm{N}$, from a distribution with theoretical mean $\mu$ and theoretical variance $\sigma^{2}$, is equal to $\sigma / \sqrt{N}$. Therefore the Student statistic for the empirical mean will be asymptotically equivalent to $t=\sqrt{N} \times \bar{x} / \sigma$. If the sample size is reduced from $\mathrm{N}$ to, say, $\mathrm{N} / 2$, the Student statistic will be asymptotically equal to $t / \sqrt{2} \simeq 0.7 \times t$. Therefore similar empirical means $\bar{x}$ on the two samples will provide lower Student statistics on the small sample even if the effect is the same.
} 


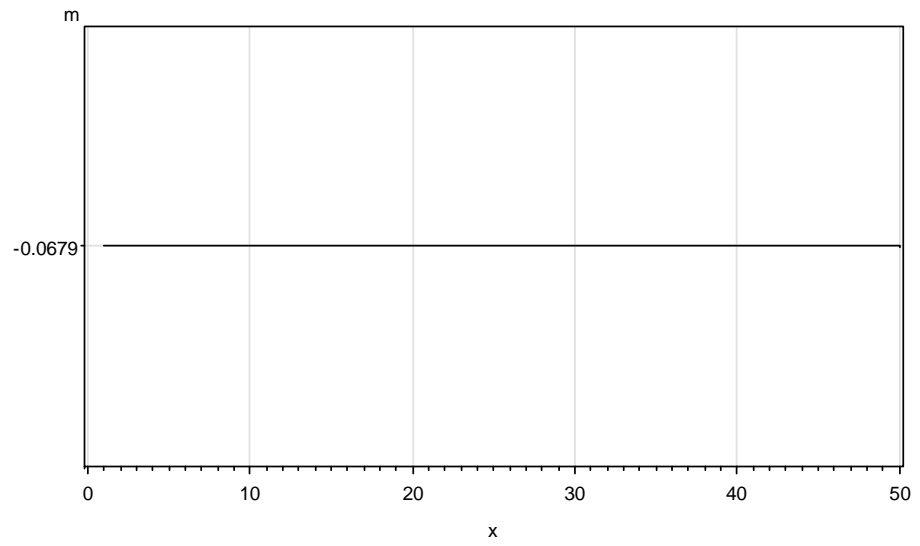

The second approach is to reduce all of these points to one: the sample mean. In kernel estimation terminology, this is equivalent to selecting a large window that covers all the lags. This is illustrated in Figure 4. We return to the ATT presented in Table 4 (-0.0679, rounded to -0.068 in Table 4). Note that the two figures are precisely equal.

To obtain information on the ATT as a function of the time lag, we need to perform local averaging, which is defined by an intermediate value of the window used in Figure 3 (equal to zero, see the scatter plot) and that used in Figure 4 (equal to 50). We ultimately selected a window equal to 20 years for our local (moving) average. We selected this value because the cross-validation method did not perform well in this application. Moreover, we needed to use the same window for all of the estimations, such that our local means are computed on the same lags for all of the performance variables.

The last point to recall here is that the number of observations in each lag interval differs, and hence, each local average does not have the same weight in the ATT. We present these weights for women in Figure 5. We find that the accidents' lags are nearly uniformly distributed, a result that reflects their inherent randomness. Conversely, the chronic illnesses' lags are more recent because they occur at a late age. Therefore, for chronic illnesses, the short lags contribute more to the ATT than the long lags.

Figure 5: Women - Distribution of the time lags since the first accident or chronic illness (in years)

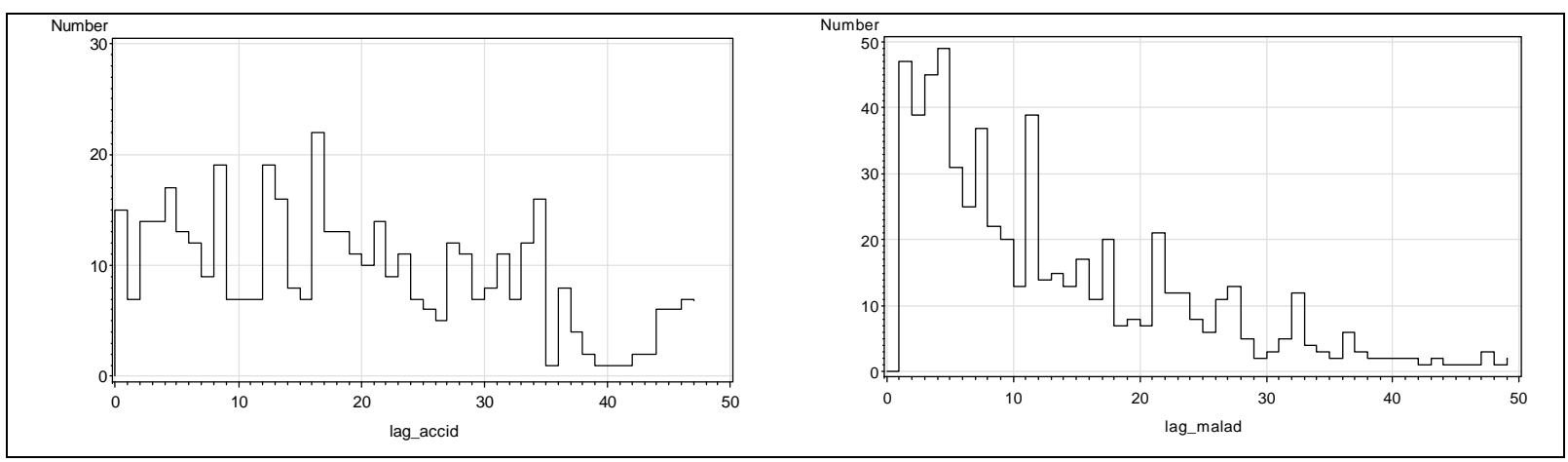


The local effects of the accidents, for women, on the main variables are summarized in Figure 6. We find that the accidents reduce labor market participation in 2006 irrespective of the lag. Consistently, we find that the accidents increase the probability of becoming a minimum assistance revenue recipient, irrespective of the lag. However, the effect is clearly increasing in the lag, and hence, this outcome is substantially influenced by accidents that occurred long ago. The local effects on income in 2006 are similar. The probability of being in the lowest income class increases in all of the accidents' lags; the probability of being in the highest income class decreases in all of the accidents' lags. However, in the latter case, the probability decreases substantially with the lag. An accident that occurred 10 years ago reduces this probability by 3 points, while an accident that occurred 25 years ago reduces it by 5 points. We conclude that accidents that occurred early in the career have a stronger effect on incomes than later accidents. The reason is that women who did not have accidents at the beginning of their careers are more likely to have obtained better-paid and betterprotected positions when the accident occurred. Therefore, the impact of recent accidents is smaller.

Figure 6: Women - local effects of accidents according to the time lag between the accident and the measurement of the output variables
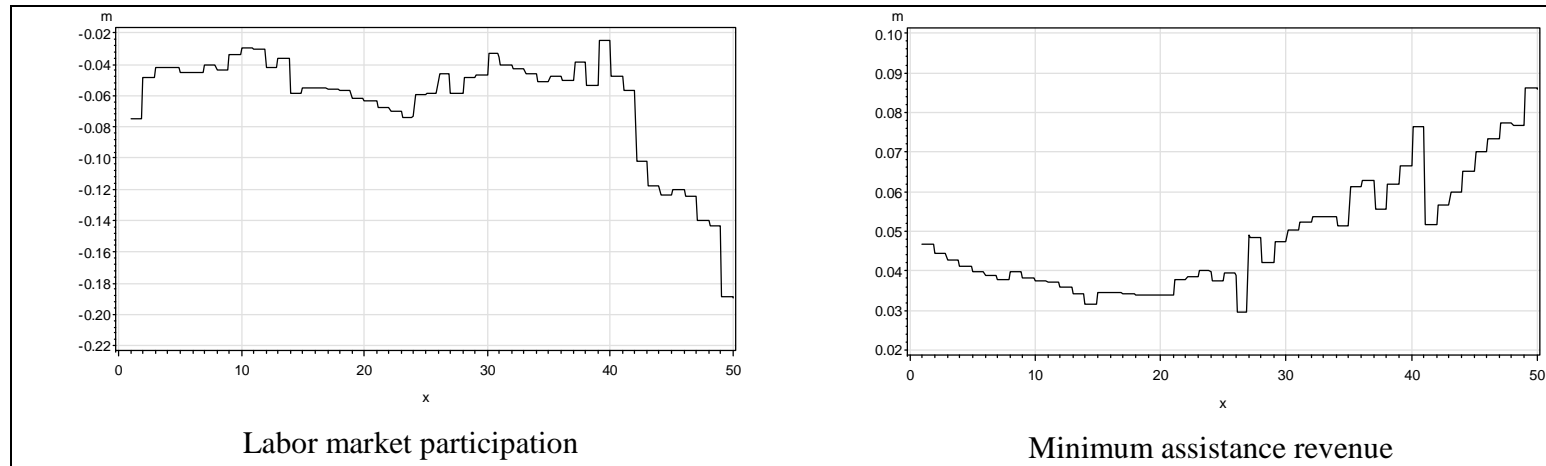


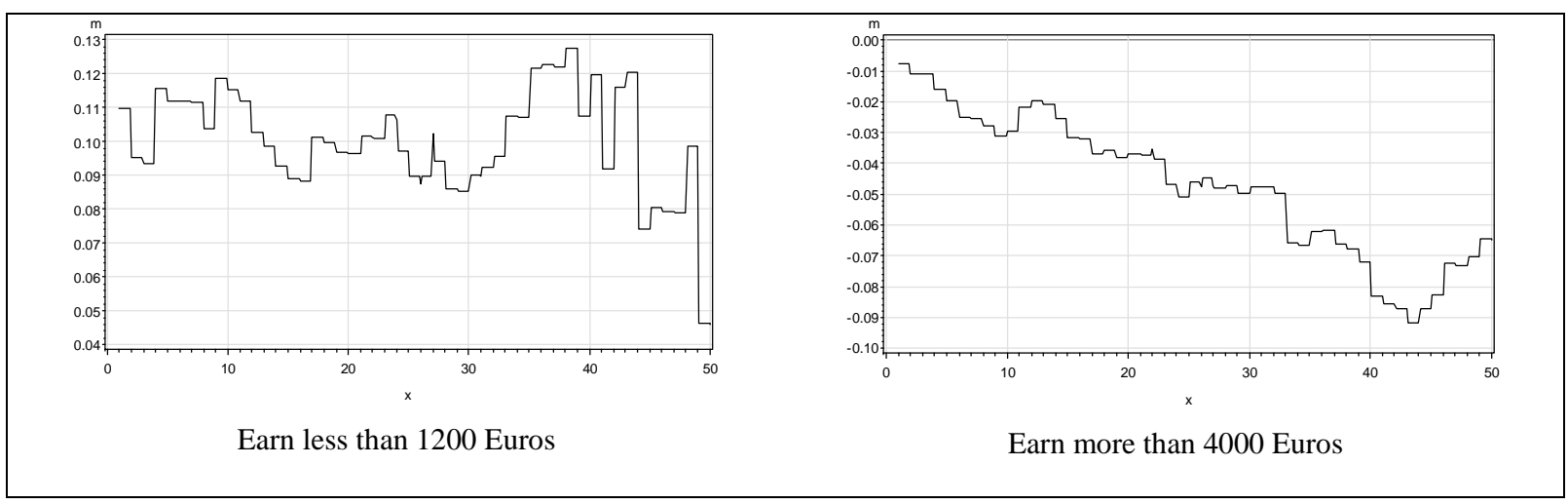

Figure 7: Women - local effects of chronic illness according to the time lag between the accident and the measurement of the output variables

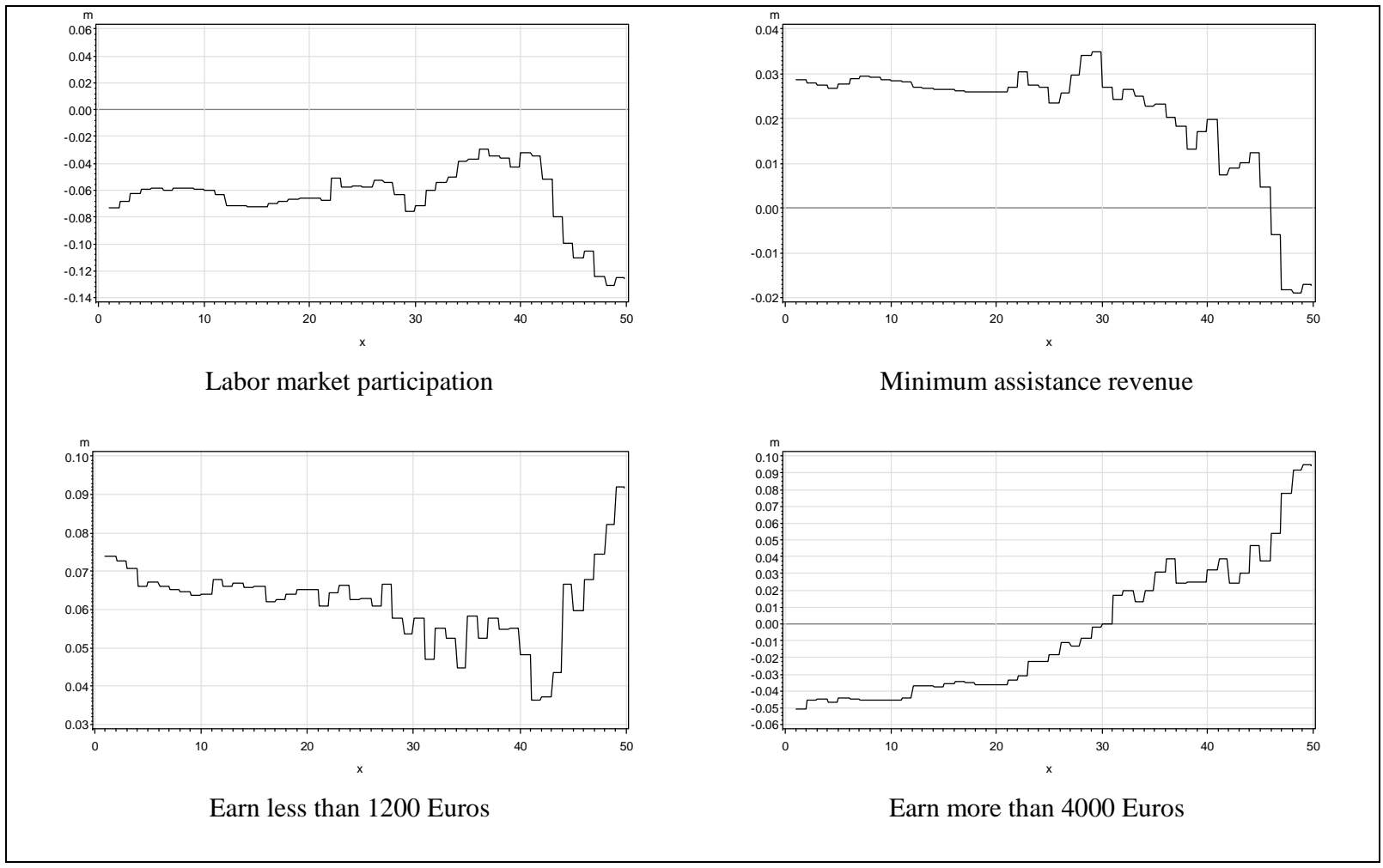

Figure 7 summarizes the local effects of chronic illnesses. As there are few observations after a 40-year lag, we will comment on the shorter lags. Chronic illnesses always have a negative effect on labor market participation. Receiving minimum assistance revenue is also more likely among ill women, as is the probability of earning fewer than 1200 Euros. Chronic illnesses clearly have a longlasting, negative effect on women's revenues. The results on the probability of earning more than 4000 Euros are interesting: while the effect is positive for the longer lags (more than 30 years), they are negative for the shorter lags. As there are few observations above zero, the global estimate is negative. At first glance, the positive effects seem disturbing. We can offer two explanations: first, the survey is performed on the survivors in 2006, and hence, the older chronic illnesses must be less incapacitating; and second, some studies have demonstrated that survivors may behave more efficiently than 
individuals who suffered no health events (for gynecological cancers, see for example, Stewart D.E., Wong F., Duff S., et al. (2001); Bradley et al. (2002)).

We now comment on the results for men. The lag distributions are presented in Figure 8 and exhibit a profile similar to those for women: accidents occur almost uniformly, and chronic illnesses are more recent.

Figure 8: Men - Distribution of the time lags since the first accident or chronic illness (in years)

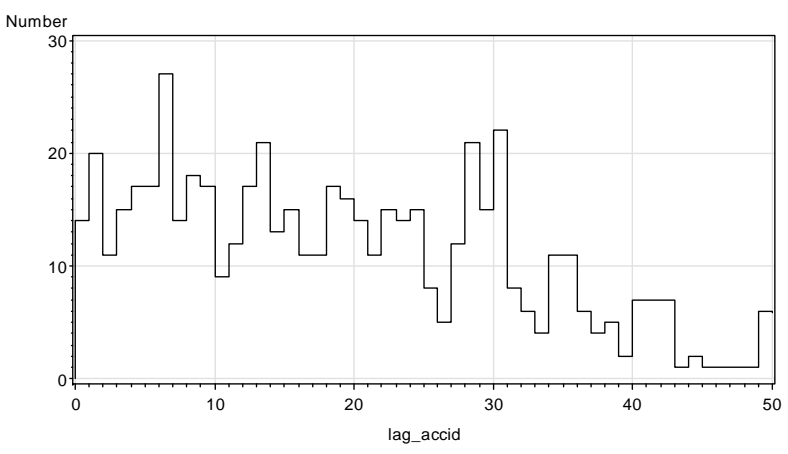

Accidents

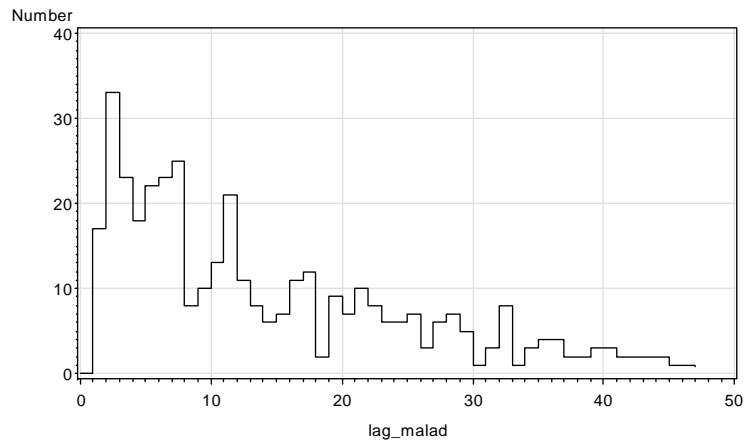

Chronic Illnesses

The results concerning accidents for men are summarized in Figure 9. We obtain a clear-cut result: all of the ATTs are dominated by short-run effects. The shorter the lag, the lower the labor market participation, the higher the probability of receiving minimum assistance revenue, the higher the probability of belonging to the lowest income class and the lower the probability of belonging to the highest income class.

Figure 10 summarizes the results on chronic illnesses for men. We also obtain a clear-cut result for three of the four variables: their ATTs are dominated by long-run effects. The longer the lag, the lower the labor market participation, the higher the probability of receiving minimum assistance revenue and the higher the probability of belonging to the lowest income class. The only exception is the probability of belonging to the highest income class: it is lower for the short lags. The results for men reveal that short-run effects dominate the results for accidents, and long-run effects dominate the results for chronic illnesses. We do not find similar results for women. In their case, the accidents may also have long-run effects.

Figure 9: Men - local effects of accidents according to the time lag between the accident and the measurement of the output variables 


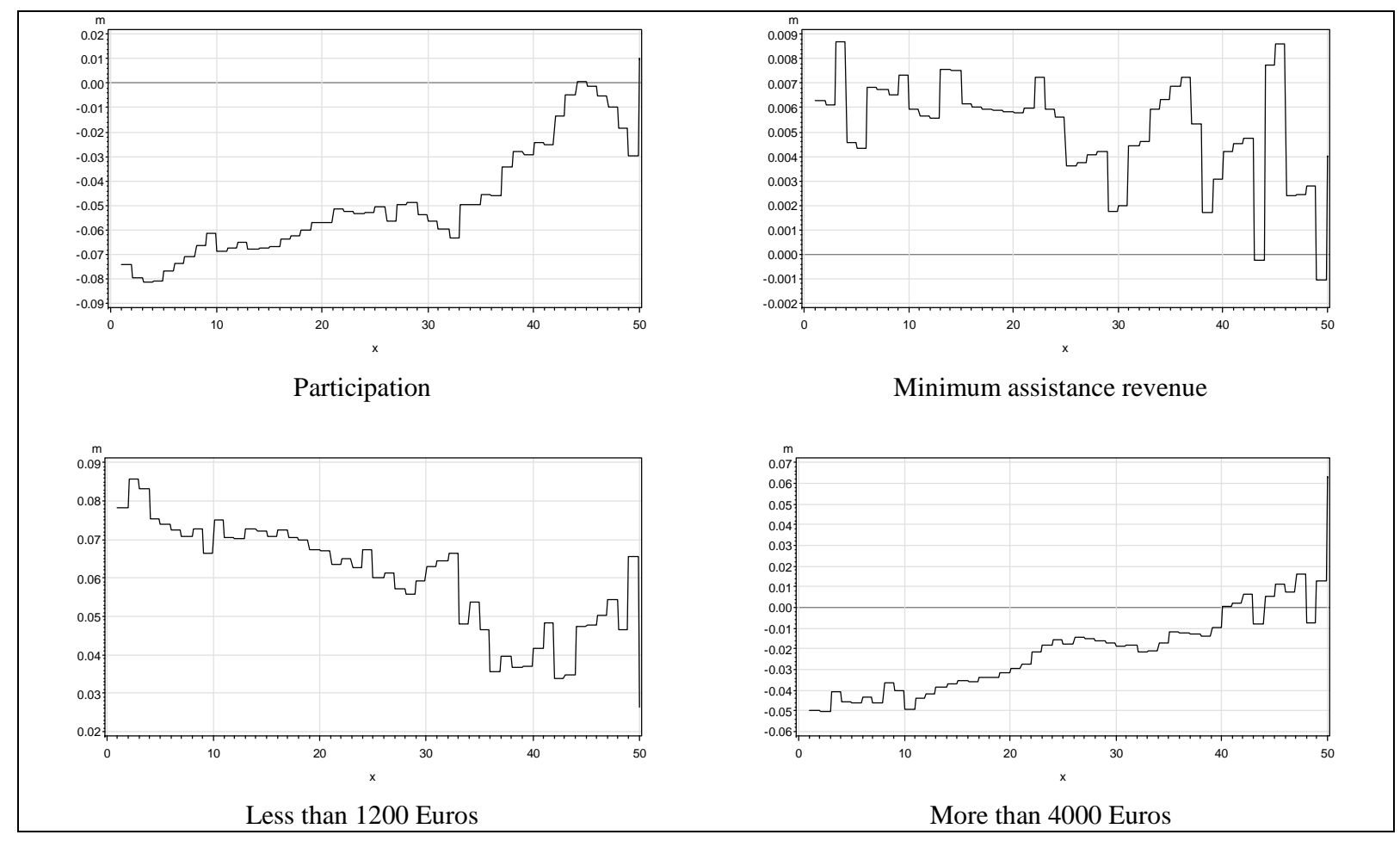

Figure 10: Men - local effects of chronic illness according to the time lag between the accident and the measurement of the output variables

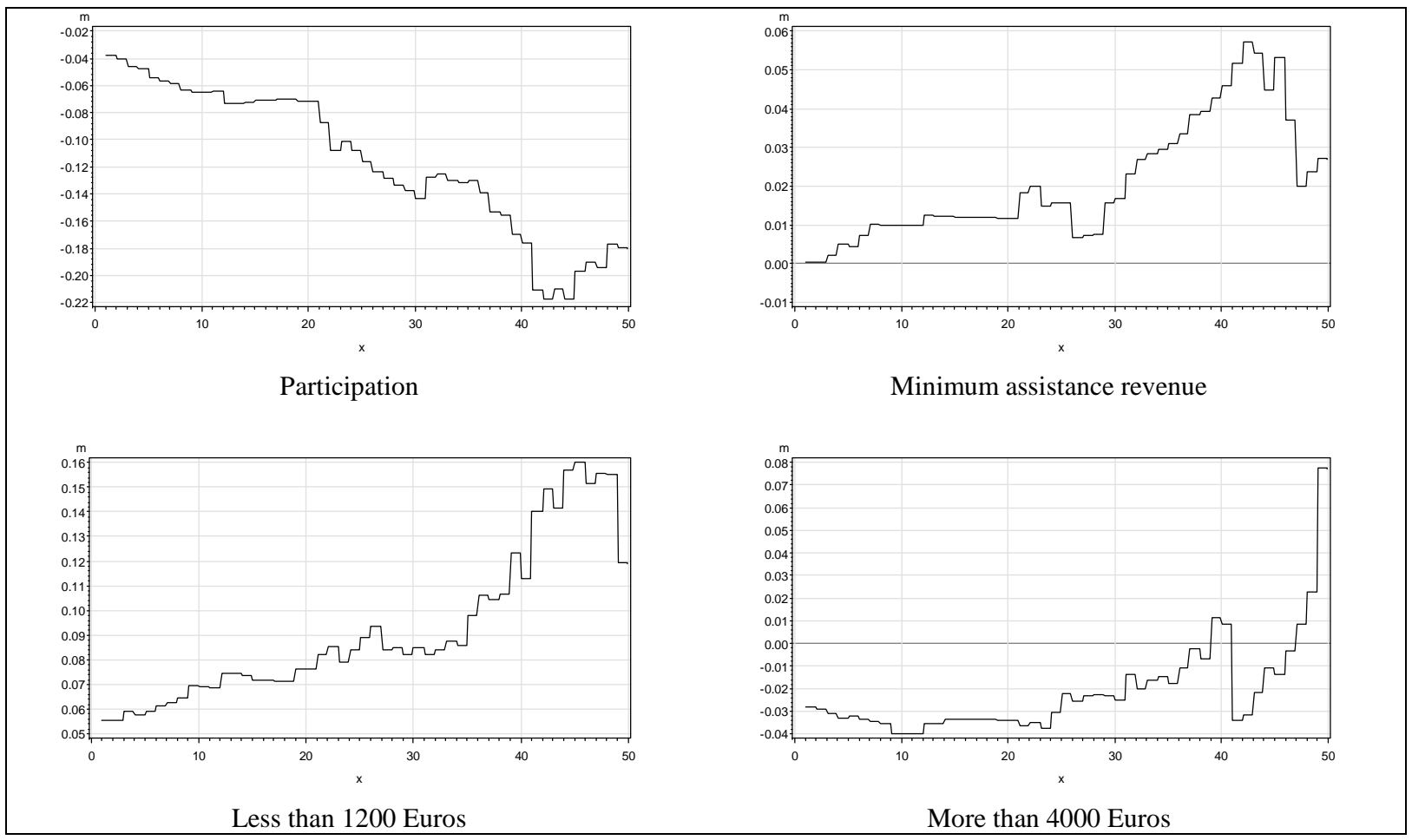

\section{Conclusion}

In this paper, we examine whether an individual's first health shock has a significant impact on future labor market performance. We find that health events in general reduce end-of-period 
participation in the labor market, income and the subjective satisfaction index regarding the individual's entire career. The predominance of ill and injured persons in the lowest part of the income distribution suggests than they face lower-wage and, likely, less stable jobs than those they would have had absent a health shock. We also find that women are at a greater disadvantage than men, as health shocks are more likely to cause them to receive minimum assistance revenue, while no significant effect is found for men. Moreover, while the first health shock has long-lasting effects in general, these effects differ by gender and the nature of the health event: the results for men demonstrate that short-run effects dominate the results for accidents and that long-run effects dominate the results for chronic illnesses. We do not find similar results for women; in their case, the accidents may also have long-run effects.

There may be several reasons that women suffer more severely than men from the consequences of ill health: this may depend on their initial status in the labor market, the difficulties in balancing family and work and perhaps the severity of health events. An improved understanding of the reasons for this disadvantage in the labor market should be developed to define adequate public policies.

However, as the first health shocks have long-lasting effects on labor market performance, health policy should be coordinated with labor policy. Prior to the passage of legislation regarding the exclusion of individuals with recognized disabilities (passed in February 2005) that mandates quotas of disabled employees in companies of more than twenty workers, no policy has focused on individuals experiencing health shocks. A policy should be developed to expedite the return to work after health events through work accommodations when sickness leave is necessary after a health shock (see, for cancer, Duguet, Le Clainche, 2012a). A second type of measure, for the workers who suffer a health shock that prevents them from performing their job, could be to encourage them to train for another type of job that is more compatible with their health problems. Similarly, for the most experienced workers, an efficient policy could be to use them as trainers to instruct younger workers. Such a coordination of health and labor policy should be able to reduce both the individual performance losses in the labor market and the cost for the health insurance system, as the new jobs would be more compatible with the workers' health problems. Finally, poor health in adulthood, which reduces labor market participation, is also the result of childhood living conditions; therefore, to ensure better health in adulthood, it is necessary to design policies to reduce poverty during childhood (Economou, Theodossiou, 2011).

We are also aware of some limitations of the study. First, the study suffers from data availability issues, as we only observe our performance variables at the end of the period, meaning that our results are only representative of the full sample at the end of the year 2006. Second, the cross-sectional data do not allow us to control for correlated unobserved heterogeneity. However, a companion study using panel data on different performance variables (Duguet and Le Clainche, 2012b), accounting for both 
individual and time-correlated effects, provides similar results. Therefore, it is possible that these biases may not be particularly important in this study.

\section{References}

Anderson K.H., Burkhauser R. V. (1985). "The Retirement-Health Nexus : A New Measure of An Old Puzzle", Journal of Human Resources 20 : 315-330.

Barnay T. (2005). « Santé déclarée et cessation d'activité ». Revue Française d'Economie, vol. XX, n 2, pp. 73-106.

Bazzoli G. ( 1985). "The Early Retirement Decision : New empirical evidence on the influence of health", Journal of Human Resources 20: 214-234.

Behaghel L., Blanchet D., Debrand T., Roger M. (2011). "Disability and Social Security Reforms: The French Case", NBER Working Paper $\mathrm{n}^{\circ} 17055$, May.

Blanchet D., Debrand T. (2007). « Souhaiter prendre sa retraite le plus tôt possible : Santé, satisfaction au travail et facteurs monétaires ». Economie et Statistique, n॰403-404, pp. 39-62.

Bound J. Schoenbaum M., Stinebrickner T. R., Waidman T. (1999). "The Dynamics Effects of Health on the Labor Force Transitions of Older Workers, Labour Economics 6 : 179-202.

Bound J. (1991). "Self-Reported versus Objective Measures of Health Retirement Models", Journal of Human Resources, vol. 26, pp. 106-138.

Bradley C.J., Bednarek H., Neumark D. (2002), "Breast Cancer Survival, Work and Earnings", Journal of Health Economics, 21 (5) : 757-779.

Case A., Fertig A., Paxson C.(2005). "The Lasting Impact of Childhood Health and Circumstance". Journal of Health Economics, 24 : 365-389.

Chirikos T. N., Nestel G. (1985). "Further evidence on the economic effects of poor health". Review of Economics and Statistics, 67 : 61-69.

Chirikos T. N., Nestel G.(1981). "Impairment and Labor Market Outcomes : A Cross Sectional and Longitudinal Analysis"in Parnes H.S. (ed.), "Work and Retirement : A Longitudinal Study of Men", MIT Press, Cambridge, pp. 91-131.

Chirikos T.N (1993). "The Relationship Between Health and Labor Market Status". Annual Review of Public Health, 14 : 293-312.

Crépon B., Jacquemet, (2010). Econométrie : Méthodes et Applications. De Boeck, ISBN 2804153231.

Crichton S., Stillman S., Hyslop D. (2011). "Returning to Work from Injury: Longitudinal Evidence on Employment and Earnings". Industrial and Labor Relations Review, 64 (4) : July, art.7.

Currie J., Madrian B. (1999). "Health, Health Insurance and the Labor Market", in Ashenfelter O., Card D.(eds), Handbook of Labor Economics, vol. 3, chap. 50, p. 3309-3416.

Debrand T., Sirven N. (2009). "What are the Motivations of Pathways to Retirement in Europe : Individual, Familial, Professional Situation of Social Protection Systems", Working Paper Irdes n 28. 2009/10.

Dehejia R., Wabba S., (2002). «Propensity Score Matching Methods for Non-Experimental Causal Studies". Review of Economics and Statistics, 84 : 151-161. 
Duguet E., du Parquet L., L'Horty Y., Petit P. (2012). "First order stochastic dominance and the measurement of hiring discrimination: A ranking extension of correspondence testing with an application to gender and origin”. Working paper, ERUDITE, September 2012.

Duguet E., Le Clainche C. (2012a). "Une évaluation de l'impact de l'aménagement des conditions de travail sur la reprise du travail après un cancer". Working paper, ERUDITE, 2012-11. HAL-SHS 00712039, LAMETA DR-2012-25, Document de travail CEE 159.

Duguet E., Le Clainche C. (2012b). « The impact of health events on individual labor market histories: the message from difference in differences with exact matching ». Working paper ERUDITE 2012/3, HAL-SHS 00674560, LAMETA DR-2012-08.

Economou A., Theodossiou I. (2011). "Poor and Sick: Estimating the Relationship Between Household Income and Health", Review of Income and Wealth, Series 57 (3) .

Garcia Gomez P., Nicholas (2006), Health shocks, Employment and Income in the Spanish Labor Market, Health Economics 15 : 997-1009.

García-Gómez P., (2011). "Institutions, health shocks and labour outcomes across Europe". Journal of Health Economics, 30: 200-213.

Givord P., (2010). "Méthodes économétriques pour l'évaluation de politiques publiques ». Document de travail INSEE, DESE G2010/8.

Haan P., Myck M. (2009). "Dynamics of Poor Health and Non-Employment", IZA Discussion Paper 4154, April, IZA.

Halla M., Zweimüller M. (2011), "The Effect of Health on Income: Quasi-Experimental Evidence from Commuting Accidents," IZA Discussion Papers 5833.

Idler E. L., Benyamini Y. (1997). "Self-rated health and mortality: a Review of twenty - seven communities studies". Journal of Health and Social Behaviour, 38 : 21-37.

Jusot F., Khlat M., Rochereau T., Sermet C. (2006). «Une mauvaise santé augmente fortement les risques de perte d'emploi », Données sociales, Insee : 533-543.

Lanoë J.L. (2005). «L'Etat de santé en France en 2003. Santé perçue, morbidité déclarée et recours aux soins à travers l'enquête décennale santé », Etudes et Résultats n436, octobre, DREES.

Lee Myoung-Jae (2005). Micro-Econometrics for Policy, Program and Treatment Effects. Oxford University Press. ISBN 0199267685.

Lindeboom M. van Doorslaer, E. (2004). "Cut-point shift and index shift in self-reported health," 23(6) :1083-1099.

Lindeboom M., Llena-Nozal A., van der Klauw B. (2006). "Disability and Work", Tinbergen Institute Discussion Paper 039/03.

Meurs D., Ponthieux S. (2000). "Une mesure de la discrimination dans l'écart de salaire entre hommes et femmes". Economie et Statistique, n³37-338, pp. 135-158.

Mitchell J. M., Burkhauser R. (1990). «Disentangling the Effect of Arthrisis on Earnings : A Simultaneous Estimate of Wage Rates and Hours Worked". Applied Economics, vol. 22, pp. 12911310.

Moller-Dano A.M. (2005). "Road Injuries and Long Run Effects on Income and Employment". Health Economics, 14 (9) : 955-970.

Riach P., Rich J. (2010). "An Experimental Investigation of Age Discrimination in the English Labor Market". Annales d'Economie et de Statistique/Annals of Economic and Statistics, ${ }^{\circ}{ }^{\circ 9}$-100, pp. 169185.

Rosenbaum P., Rubin D. (1985). "Constructing a control group using multivariate matched sampling methods that incorporate the propensity score". The American Statistician; vol. 39, n 1, 33-38. 
Rosenbaum P.R., Rubin D. (1983). "The Central Role of the Propensity Score in Observational Studies for Causal Effects". Biometrika, 70 (1), 41-55.

Rubin D. (2006). Matched sampling for causal effects. Cambridge University Press, ISBN: 9780521674362 .

Rubin D., Thomas N. (1996). "Matching using estimated propensity scores, relating theory to practice". Biometrics, 52:249-64.

Stern S., (1989). "Measuring The Effect of Disability on Labor Force Participation", Journal of

Human Resources 24 : 361-395.

Stewart D. E., Wong F., Duff S., et al. (2001). "What Doesn't Kill you Makes you Stronger": An Ovarian Cancer Survivor Survey, Gynecologic Oncology, 83(3) : 537-542.

Tessier P., Wolff F.C. (2005), « Offre de travail et santé en France », Economie et Prévision, vol. 2 pp. $17-41$.

Trannoy A., Tubeuf S., Jusot F., Devaux M. (2010). "Inequality of Opportunities in health in France: A first Pass", Health Economics 19 (8) : 921-938.

Wadsworth M., Butterworth S. (2006). "Early Life", in Marmot M., Wilkinson R. (2006), Social Determinants of Health, Oxford University Press, Chap. 3, 31-53.

Zucchelli E., Harris M., Zhao X. (2012). "Ill-Health and Transitions to Part-Time Work and the SelfEmployment Among Olders Workers", HEDG WP 12/04. 
Table 2: Women - sample statistics

${ }^{* *}$ : significant at the $5 \%$ level; *: significant at the $10 \%$ level.

\begin{tabular}{|c|c|c|c|c|c|c|c|}
\hline \multirow[t]{2}{*}{ Sample } & \multirow{2}{*}{$\begin{array}{c}\begin{array}{c}\text { Neither } \\
\text { accident nor } \\
\text { chronic } \\
\text { disease }\end{array} \\
\text { (1) }\end{array}$} & \multirow{2}{*}{$\begin{array}{c}\text { Accident } \\
\text { (2) }\end{array}$} & \multirow{2}{*}{$\begin{array}{c}\begin{array}{c}\text { Chronic } \\
\text { disease }\end{array} \\
\text { (3) }\end{array}$} & \multirow{2}{*}{$\begin{array}{c}\text { Difference: } \\
\text { Accident } \\
\text { (2)-(1) }\end{array}$} & \multirow[t]{2}{*}{ Student } & \multirow{2}{*}{$\begin{array}{c}\text { Difference: } \\
\text { Chronic } \\
\text { disease }\end{array}$} & \multirow[t]{2}{*}{ Student } \\
\hline & & & & & & & \\
\hline Sample size & 2731 & 432 & 627 & - & - & - & - \\
\hline \multicolumn{8}{|l|}{ Matching variables } \\
\hline $\begin{array}{l}\text { Age } \\
\text { Education: }\end{array}$ & 38.25 & 42.03 & 42.38 & $3.78^{* *}$ & 7.03 & $4.13^{* *}$ & 9.55 \\
\hline Primary & $16.0 \%$ & $19.7 \%$ & $24.1 \%$ & $3.7 \% *$ & 1.82 & $8.1 \% * *$ & 4.39 \\
\hline Secondary & $31.5 \%$ & $39.6 \%$ & $33.5 \%$ & $8.1 \% * *$ & 3.23 & $2.0 \%$ & 0.98 \\
\hline Post- secondary & $52.6 \%$ & $40.7 \%$ & $42.4 \%$ & $-11.8 \% * *$ & 4.64 & $-10.2 \% * *$ & 4.63 \\
\hline \multicolumn{8}{|l|}{ Origin: } \\
\hline Foreign mother & $14.9 \%$ & $13.7 \%$ & $16.1 \%$ & $-1.2 \%$ & 0.70 & $1.2 \%$ & 0.74 \\
\hline Foreign father & $14.4 \%$ & $10.4 \%$ & $16.6 \%$ & $-4.0 \% * *$ & 2.48 & $2.2 \%$ & 1.32 \\
\hline Born in France & $88.8 \%$ & $86.3 \%$ & $87.2 \%$ & $-2.4 \%$ & 1.37 & $-1.5 \%$ & 1.04 \\
\hline \multicolumn{8}{|l|}{ Childhood: } \\
\hline Raised by the mother & $88.4 \%$ & $83.8 \%$ & $86.0 \%$ & $-4.6 \% * *$ & 2.47 & $-2.5 \%$ & 1.62 \\
\hline Raised by the father & $96.6 \%$ & $93.1 \%$ & $93.1 \%$ & $-3.5 \% * *$ & 2.78 & $-3.5 \% * *$ & 3.23 \\
\hline Separated from family & $10.9 \%$ & $22.5 \%$ & $17.2 \%$ & $11.6 \% * *$ & 5.52 & $6.3 \% * *$ & 3.91 \\
\hline Parents had serious health problems & $12.9 \%$ & $23.4 \%$ & $20.1 \%$ & $10.5 \% * *$ & 4.89 & $7.2 \% * *$ & 4.16 \\
\hline \multicolumn{8}{|l|}{ Performance variables } \\
\hline Worked last week & $71.3 \%$ & $66.0 \%$ & $65.6 \%$ & $-5.3 \% * *$ & 2.18 & $-5.7 \% * *$ & 2.75 \\
\hline $\begin{array}{l}\text { Number of hours worked last week } \\
\text { (if }>0 \text { ) } \\
\text { Household monthly income: }\end{array}$ & 35.76 & 34.24 & 33.89 & $-1.52 * *$ & 2.07 & $-1.87^{* *}$ & 2.97 \\
\hline Missing & $4.5 \%$ & $0.9 \%$ & $4.6 \%$ & $-3.6 \% * *$ & 5.88 & $0.1 \%$ & 0.13 \\
\hline Fewer than 1200 Euros & $15.0 \%$ & $25.7 \%$ & $22.2 \%$ & $10.7 \% * *$ & 4.84 & $7.2 \% * *$ & 4.01 \\
\hline $1200-2500$ & $39.6 \%$ & $41.0 \%$ & $38.0 \%$ & $1.4 \%$ & 0.55 & $-1.6 \%$ & 0.75 \\
\hline $2500-4000$ & $28.3 \%$ & $22.5 \%$ & $25.8 \%$ & $-5.8 \% * *$ & 2.66 & $-2.4 \%$ & 1.25 \\
\hline More than 4000 Euros & $12.7 \%$ & $10.0 \%$ & $9.4 \%$ & $-2.7 \% *$ & 1.72 & $-3.3 \% * *$ & 2.45 \\
\hline $\begin{array}{l}\text { Minimum assistance revenue last } \\
\text { month }\end{array}$ & $3.3 \%$ & $8.6 \%$ & $5.7 \%$ & $5.3 \% * *$ & 3.79 & $2.4 \% * *$ & 2.47 \\
\hline Subjective satisfaction with career & 7.31 & 6.82 & 6.83 & $-0.49 * *$ & 3.65 & $-0.48 * *$ & 4.18 \\
\hline
\end{tabular}


Table 3: Men - sample statistics

${ }^{* *}$ : significant at the $5 \%$ level; * : significant at the $10 \%$ level.

\begin{tabular}{|c|c|c|c|c|c|c|c|}
\hline \multirow[t]{2}{*}{ Sample } & \multirow{2}{*}{$\begin{array}{c}\text { Neither } \\
\text { accident nor } \\
\text { chronic } \\
\text { disease }\end{array}$} & Accident & $\begin{array}{l}\text { Chronic } \\
\text { disease }\end{array}$ & $\begin{array}{c}\text { Difference: } \\
\text { Accident }\end{array}$ & \multirow[t]{2}{*}{ Student } & \multirow{2}{*}{$\begin{array}{c}\text { Difference: } \\
\text { Chronic } \\
\text { disease }\end{array}$} & \multirow[t]{2}{*}{ Student } \\
\hline & & (2) & (3) & (2)-(1) & & & \\
\hline Sample size & 2073 & 538 & 378 & - & - & - & - \\
\hline \multicolumn{8}{|l|}{ Matching variables } \\
\hline \multicolumn{8}{|l|}{ Education: } \\
\hline Primary & $15.6 \%$ & $13.6 \%$ & $19.3 \%$ & $-2.0 \%$ & 1.20 & $3.7 \% *$ & 1.71 \\
\hline Secondary & $38.6 \%$ & $44.4 \%$ & $46.8 \%$ & $5.8 \% * *$ & 2.43 & $8.2 \% * *$ & 2.96 \\
\hline Post- secondary & $45.8 \%$ & $42.0 \%$ & $33.9 \%$ & $-3.8 \%$ & 1.60 & $-12.0 \% * *$ & 4.48 \\
\hline \multicolumn{8}{|l|}{ Origin: } \\
\hline Foreign mother & $17.0 \%$ & $12.8 \%$ & $14.3 \%$ & $-4.2 \% * *$ & 2.53 & $-2.7 \%$ & 1.38 \\
\hline Foreign father & $15.8 \%$ & $11.9 \%$ & $14.3 \%$ & $-3.9 \% * *$ & 2.44 & $-1.5 \%$ & 0.78 \\
\hline Born in France & $87.5 \%$ & $89.6 \%$ & $88.1 \%$ & $2.1 \%$ & 1.39 & $0.6 \%$ & 0.32 \\
\hline \multicolumn{8}{|l|}{ Childhood: } \\
\hline Raised by the mother & $89.5 \%$ & $86.6 \%$ & $87.3 \%$ & $-2.9 \% *$ & 1.77 & $-2.2 \%$ & 1.18 \\
\hline Raised by the father & $96.6 \%$ & $95.7 \%$ & $95.8 \%$ & $-0.9 \%$ & 0.89 & $-0.8 \%$ & 0.73 \\
\hline Separated from family & $10.8 \%$ & $16.2 \%$ & $13.2 \%$ & $5.4 \% * *$ & 3.10 & $2.4 \%$ & 1.29 \\
\hline Parents had serious health problems & $10.9 \%$ & $22.1 \%$ & $14.8 \%$ & $11.2 \% * *$ & 5.85 & $3.9 \% * *$ & 2.00 \\
\hline \multicolumn{8}{|l|}{ Performance variables } \\
\hline Worked last week & $83.4 \%$ & $82.9 \%$ & $79.1 \%$ & $-0.5 \%$ & 0.28 & $-4.3 \% *$ & 1.92 \\
\hline $\begin{array}{l}\text { Number of hours worked last week } \\
\text { (if }>0 \text { ) }\end{array}$ & 41.65 & 40.68 & 39.62 & $-0.97 *$ & 1.70 & $-2.03 * *$ & 3.12 \\
\hline \multicolumn{8}{|l|}{ Household monthly income: } \\
\hline Missing & $4.0 \%$ & $3.2 \%$ & $1.9 \%$ & $-0.8 \%$ & 0.97 & $-2.2 \% * *$ & 2.63 \\
\hline Fewer than 1200 Euros & $11.1 \%$ & $14.5 \%$ & $16.7 \%$ & $3.4 \% * *$ & 2.01 & $5.5 \% * *$ & 2.71 \\
\hline $1200-2500$ & $39.2 \%$ & $38.3 \%$ & $41.3 \%$ & $-0.9 \%$ & 0.39 & $2.1 \%$ & 0.75 \\
\hline $2500-4000$ & $31.2 \%$ & $32.0 \%$ & $30.2 \%$ & $0.8 \%$ & 0.36 & $-1.0 \%$ & 0.39 \\
\hline More than 4000 Euros & $14.5 \%$ & $12.1 \%$ & $10.1 \%$ & $-2.4 \%$ & 1.49 & $-4.4 \% * *$ & 2.55 \\
\hline $\begin{array}{l}\text { Minimum assistance revenue last } \\
\text { month }\end{array}$ & $1.6 \%$ & $2.0 \%$ & $3.2 \%$ & $0.4 \%$ & 0.60 & $1.5 \%$ & 1.62 \\
\hline Subjective satisfaction with career & 7.50 & 7.13 & 6.92 & $-0.37 * *$ & 3.38 & $-0.58 * *$ & 4.42 \\
\hline
\end{tabular}


Table 4: Effect of a health event on the end-of-period performance variables

Average effect of the treatment on the treated (ATT). Matching using the propensity score (Rosenbaum and Rubin, 1983). **: significant at the $5 \%$ level; *: significant at the $10 \%$ level.

\begin{tabular}{|c|c|c|c|c|}
\hline & \multicolumn{4}{|c|}{ Women } \\
\hline & \multicolumn{2}{|c|}{ Accident } & \multicolumn{2}{|c|}{ Chronic illness } \\
\hline Worked last month & $-0.068 * *$ & 2.17 & $-0.066 * *$ & 2.64 \\
\hline Number of hours worked (if $>0$ ) & -0.854 & 0.91 & $-1.572 * *$ & 2.00 \\
\hline \multicolumn{5}{|l|}{ Household income: } \\
\hline Missing & $-0.032 * *$ & 2.99 & 0.000 & 0.34 \\
\hline Fewer than 1200 Euros & $0.103^{* *}$ & 3.87 & $0.066 * *$ & 3.05 \\
\hline 1200-2500 Euros & 0.005 & 0.33 & -0.005 & 0.35 \\
\hline 2500-4000 Euros & -0.037 & 1.26 & -0.028 & 1.12 \\
\hline More than 4000 Euros & $-0.039 *$ & 1.78 & $-0.033^{*}$ & 1.93 \\
\hline Minimum assistance revenue last month & $0.049 * *$ & 3.05 & $0.025 * *$ & 2.07 \\
\hline \multirow[t]{3}{*}{ Overall degree of career satisfaction } & $-0.491 * *$ & 3.08 & $-0.393 * *$ & 2.83 \\
\hline & \multicolumn{4}{|c|}{ Men } \\
\hline & \multicolumn{2}{|c|}{ Accident } & \multicolumn{2}{|c|}{ Chronic illness } \\
\hline Worked last month & $-0.055^{* *}$ & 2.76 & $-0.075^{* *}$ & 2.91 \\
\hline Number of hours worked (if $>0$ ) & $-1.312^{*}$ & 1.81 & $-2.618 * *$ & 2.96 \\
\hline \multicolumn{5}{|l|}{ Household income: } \\
\hline Missing & -0.004 & 0.42 & -0.014 & 1.18 \\
\hline Fewer than 1200 Euros & $0.066 * *$ & 3.43 & $0.074 * *$ & 3.27 \\
\hline 1200-2500 Euros & -0.022 & 0.76 & 0.007 & 0.37 \\
\hline 2500-4000 Euros & -0.010 & 0.42 & -0.037 & 1.12 \\
\hline More than 4000 Euros & -0.029 & 1.55 & -0.029 & 1.28 \\
\hline Minimum assistance revenue last month & 0.006 & 0.71 & 0.011 & 1.00 \\
\hline Overall degree of career satisfaction & $-0.393 * *$ & 3.00 & $-0.564 * *$ & 3.59 \\
\hline
\end{tabular}


Table 5: Effect of the first accident according to the age at which it occurred

Average effect of the treatment on the treated (ATT). Matching using the propensity score (Rosenbaum and Rubin, 1983). **: significant at the $5 \%$ level; *: significant at the $10 \%$ level.

\begin{tabular}{|c|c|c|c|c|}
\hline \multirow[b]{3}{*}{ Worked last month } & \multicolumn{4}{|c|}{ Women } \\
\hline & \multicolumn{2}{|c|}{ Early Accident (Age<24) } & \multicolumn{2}{|c|}{ Late Accident (Age $\geq 24)$} \\
\hline & $-0.141^{* *}$ & 3.24 & 0.024 & 0.59 \\
\hline Number of hours worked (if $>0$ ) & -1.175 & 0.81 & $-2.295^{* *}$ & 1.97 \\
\hline \multicolumn{5}{|l|}{ Household income: } \\
\hline Missing & $-0.034 * *$ & 2.18 & $-0.039 * *$ & 2.52 \\
\hline Fewer than 1200 Euros & $0.070^{*}$ & 1.82 & $0.101^{* *}$ & 2.71 \\
\hline 1200-2500 Euros & 0.018 & 0.48 & 0.036 & 0.79 \\
\hline 2500-4000 Euros & -0.053 & 1.32 & -0.031 & 0.76 \\
\hline More than 4000 Euros & 0.000 & 0.35 & $-0.067 * *$ & 2.20 \\
\hline Minimum assistance revenue last month & $0.041^{*}$ & 1.79 & $0.055^{* *}$ & 2.45 \\
\hline \multirow[t]{3}{*}{ Overall degree of career satisfaction } & $-0.510^{*}$ & 1.93 & $-0.399 *$ & 1.85 \\
\hline & \multicolumn{4}{|c|}{ Men } \\
\hline & \multicolumn{2}{|c|}{ Early Accident (Age<24) } & \multicolumn{2}{|c|}{ Late Accident (Age $\geq 24$ ) } \\
\hline Worked last month & -0.024 & 0.91 & $-0.082 * *$ & 2.88 \\
\hline Number of hours worked (if $>0$ ) & -0.355 & 0.49 & $-2.825 * *$ & 2.33 \\
\hline \multicolumn{5}{|l|}{ Household income: } \\
\hline Missing & -0.015 & 0.93 & 0.010 & 0.66 \\
\hline Fewer than 1200 Euros & $0.050 * *$ & 2.00 & $0.070 * *$ & 2.53 \\
\hline 1200-2500 Euros & -0.018 & 0.50 & -0.003 & 0.35 \\
\hline 2500-4000 Euros & -0.039 & 1.04 & -0.018 & 0.49 \\
\hline More than 4000 Euros & 0.021 & 0.84 & $-0.058 * *$ & 2.12 \\
\hline Minimum assistance revenue last month & 0.008 & 0.72 & -0.005 & 0.39 \\
\hline Overall degree of career satisfaction & -0.151 & 0.82 & $-0.424 * *$ & 2.15 \\
\hline
\end{tabular}


Table 6: Effect of the first chronic illness depending on the age at which it occurred

Average effect of the treatment on the treated (ATT). Matching using the propensity score (Rosenbaum and Rubin, 1983). **: significant at the $5 \%$ level; *: significant at the $10 \%$ level.

\begin{tabular}{|c|c|c|c|c|}
\hline \multirow[b]{3}{*}{ Worked last month } & \multicolumn{4}{|c|}{ Women } \\
\hline & \multicolumn{2}{|c|}{ Early illness (Age<33) } & \multicolumn{2}{|c|}{ Late illness (Age $\geq 33$ ) } \\
\hline & $-0.075^{* *}$ & 2.09 & $-0.077^{* *}$ & 2.20 \\
\hline Number of hours worked (if $>0$ ) & $-2.203^{* *}$ & 2.11 & -0.852 & 0.75 \\
\hline \multicolumn{5}{|l|}{ Household income: } \\
\hline Missing & 0.002 & 0.42 & 0.004 & 0.40 \\
\hline Fewer than 1200 Euros & $0.086 * *$ & 2.86 & 0.043 & 1.43 \\
\hline 1200-2500 Euros & -0.018 & 0.53 & -0.002 & 0.31 \\
\hline 2500-4000 Euros & $-0.059 *$ & 1.69 & 0.005 & 0.34 \\
\hline More than 4000 Euros & -0.012 & 0.58 & $-0.050 * *$ & 2.08 \\
\hline Minimum assistance revenue last month & 0.003 & 0.30 & $0.032 *$ & 1.88 \\
\hline \multirow[t]{3}{*}{ Overall degree of career satisfaction } & -0.315 & 1.55 & $-0.425^{* *}$ & 2.19 \\
\hline & \multicolumn{4}{|c|}{ Men } \\
\hline & \multicolumn{2}{|c|}{ Early illness (Age<33) } & \multicolumn{2}{|c|}{ Late illness (Age $\geq 33$ ) } \\
\hline Worked last month & $-0.062 *$ & 1.75 & -0.053 & 1.42 \\
\hline Number of hours worked (if $>0$ ) & -1.742 & 1.46 & $-3.043 * *$ & 2.48 \\
\hline \multicolumn{5}{|l|}{ Household income: } \\
\hline Missing & -0.025 & 1.30 & -0.016 & 0.98 \\
\hline Fewer than 1200 Euros & $0.064^{*}$ & 1.78 & $0.066 * *$ & 2.09 \\
\hline 1200-2500 Euros & 0.016 & 0.47 & 0.063 & 1.24 \\
\hline 2500-4000 Euros & -0.055 & 1.22 & -0.043 & 0.87 \\
\hline More than 4000 Euros & 0.000 & 0.39 & $-0.070 * *$ & 2.28 \\
\hline Minimum assistance revenue last month & 0.010 & 0.71 & 0.010 & 0.60 \\
\hline Overall degree of career satisfaction & $-0.734^{* *}$ & 3.27 & $-0.732 * *$ & 3.44 \\
\hline
\end{tabular}




\section{Table 7: Effect of selected types of chronic illness}

In this variant, we excluded the following chronic illnesses: deafness, tinnitus, slipped disc, bone diseases and articulation diseases.

Average effect of the treatment on the treated (ATT). Matching using the propensity score (Rosenbaum and Rubin, 1983). **: significant at the $5 \%$ level; *: significant at the $10 \%$ level.

\begin{tabular}{|l|ll|cc|}
\hline \hline & \multicolumn{2}{|c|}{ Women } & \multicolumn{2}{c|}{ Men } \\
\hline Worked last month & $-0.092^{* *}$ & 2.96 & $-0.126^{* *}$ & 3.63 \\
Number of hours worked (if $>0$ ) & $-2.522^{* *}$ & 2.50 & $-3.124^{* *}$ & 2.65 \\
Household income: & & & & \\
Missing & -0.004 & 0.41 & -0.013 & 0.76 \\
Fewer than 1200 Euros & $0.056^{* *}$ & 2.04 & $0.096^{* *}$ & 2.75 \\
$1200-2500$ Euros & -0.001 & 0.33 & 0.020 & 0.51 \\
$2500-4000$ Euros & -0.028 & 0.93 & $-0.087^{* *}$ & 2.06 \\
More than 4000 Euros & -0.023 & 1.20 & -0.017 & 0.64 \\
Minimum assistance revenue last month & 0.024 & 1.51 & 0.023 & 1.63 \\
Overall degree of career satisfaction & -0.267 & 1.34 & $-0.872^{* *}$ & 3.65 \\
\hline \hline
\end{tabular}




\section{APPENDIX}

\section{Propensity scores}

We estimated the propensity scores using a Probit model. Following Rubin and Thomas (1996), we retained all of the variables in the regression to perform the matching. The following list of variables was employed:

General variables:

- Age and age squared

- Education: 8-level decomposition (more detailed than the one presented in the sample statistics)

- Foreign father (yes/no)

- Foreign mother (yes/no)

- Born in France (yes/no)

Childhood dummies:

- $\quad$ Separated from the mother (yes/no)

- Separated from the father (yes/no)

- The parents had serious health problems (yes/no)

The Probit regression results are available from the authors on request.

Table A.1: Time lag between the first health event and the outcome variable

\begin{tabular}{lcccc}
\hline \hline (years) & \multicolumn{2}{c}{ Men } & \multicolumn{2}{c}{ Women } \\
\hline & Accident & $\begin{array}{c}\text { Chronic } \\
\text { illness }\end{array}$ & Accident & $\begin{array}{c}\text { Chronic } \\
\text { illness }\end{array}$ \\
\cline { 2 - 5 } $25^{\text {th }}$ percentile & 7 & 4 & 8 & 3 \\
Median & 17 & 9 & 17 & 8 \\
$75^{\text {th }}$ percentile & 27 & 19 & 27 & 18 \\
Mean & 17.6 & 12.2 & 17.9 & 11.8 \\
\hline \hline
\end{tabular}

Reading example: on average, for men, there is a lag of 12.2 years between the first chronic disease and the outcome variables. For women, the median lag between the first accident and the outcome variables is 17 years. 
14_4. Retirement intentions in the presence of technological change: Theory and evidence from France

Pierre-Jean Messe, Eva Moreno - Galbis, Francois-Charles Wolff

14_3. Why is Old Workers' Labor Market more Volatile? Unemployment Fluctuations over the Life-Cycle

Jean-Olivier Hairault, François Langot, Thepthida Sopraseuth

14_2. Participation, Recruitment Selection, and the Minimum Wage

Frédéric Gavrel

14_1. Disparities in taking sick leave between sectors of activity in France: a longitudinal analysis of administrative data

Thomas Barnay, Sandrine Juin, Renaud Legal

\section{TEPP Working Papers 2013}

13_9. An evaluation of the impact of industrial restructuring on individual human capital accumulation in France (1956-1993)

Nicolas Fleury, Fabrice Gilles

13_8. On the value of partial commitment for cooperative investment in buyer-supplier relationship

José de Sousa, Xavier Fairise

13-7. Search frictions, real wage rigidities and the optimal design of unemployment insurance

Julien Albertini, Xavier Fairise

13-6. Tax me if you can! Optimal non linear income tax between competing governments Etienne Lehmann, Laurent Simula, Alain Trannoy

13-5. Beyond the labour income tax wedge: The unemployment-reducing effect of tax progressivity

Etienne Lehmann, Claudio Lucifora, Simone Moriconi, Bruno Van Der Linden

13-4. Discrimination based on place of residence and access to employment Mathieu Bunel, Emilia Ene Jones, Yannick L'Horty, Pascale Petit

12-3. The determinants of job access channels: evidence from the youth labor market in Franc

Jihan Ghrairi

13-2. Capital mobility, search unemployment and labor market policies: The case of minimum wages

Frédéric Gavrel

13-1. Effort and monetary incentives in Nonprofit et For-Profit Organizations Joseph Lanfranchi, Mathieu Narcy 
The CNRS Institute for Labor Studies and Public Policies (the TEPP Institute, FR $n^{\circ} 3435$ CNRS) gathers together research centres specializing in economics and sociology:

- l'Equipe de Recherche sur les Marchés, l'Emploi et la Simulation (Research Team on Markets, Employment and Simulation), ERMES, University of Paris II PanthéonAssas

- the Centre d'Etudes des Politiques Economiques de l'université d'Evry (Research Centre focused on the analysis of economic policy and its foundations and implications), EPEE, University of Evry Val d'Essonne

- the Centre Pierre Naville (Research on Work and Urban Policies), CPN, University of Evry Val d'Essonne

- l'Equipe de Recherche sur l'Utilisation des Données Temporelles en Economie (Research Team on Use of Time Data in Economics), ERUDITE, University of ParisEst Créteil and University of Paris-Est Marne-la-Vallée

- the Groupe d'Analyse des Itinéraires et des Niveaux Salariaux (The Group on Analysis of Wage Levels and Trajectories), GAINS, University of the Maine

The TEPP Institute brings together 147 researchers and research professors and $100 \mathrm{PhD}$ students who study changes in work and employment in relation to the choices made by firms and analyse public policies using new evaluation methods. 